\title{
Air quality and emissions in the Yangtze River Delta, China
}

\author{
L. Li ${ }^{1}$, C. H. Chen ${ }^{1}$, J. S. Fu ${ }^{2}$, C. Huang ${ }^{1}$, D. G. Streets ${ }^{3}$, H. Y. Huang ${ }^{1}$, G. F. Zhang ${ }^{1}$, Y. J. Wang ${ }^{4}$, C. J. Jang ${ }^{5}$, \\ H. L. Wang ${ }^{1}$, Y. R. Chen ${ }^{1}$, and J. M. Fu ${ }^{4}$ \\ ${ }^{1}$ Shanghai Academy of Environmental Sciences, Shanghai, 200233, China \\ ${ }^{2}$ Department of Civil and Environmental Engineering, University of Tennessee, Knoxville, TN 37996, USA \\ ${ }^{3}$ Decision and Information Sciences Division, Argonne National Laboratory, Argonne, IL 60439, USA \\ ${ }^{4}$ Institute of Environmental Pollution and Health, School of Environmental and Chemical Engineering, Shanghai University, \\ Shanghai 200444, China \\ ${ }^{5}$ Office of Air Quality Planning and Standards, US Environmental Protection Agency, Research Triangle Park, \\ NC 27711, USA
}

Received: 23 August 2010 - Published in Atmos. Chem. Phys. Discuss.: 12 October 2010

Revised: 31 January 2011 - Accepted: 9 February 2011 - Published: 21 February 2011

\begin{abstract}
Regional trans-boundary air pollution has become an important issue in the field of air pollution modeling. This paper presents the results of the implementation of the MM5CMAQ modeling system in the Yangtze River Delta (YRD) for the months of January and July of 2004. The meteorological parameters are obtained by using the MM5 model. A new regional emission inventory with spatial and temporal allocations based on local statistical data has been developed to provide input emissions data to the MM5-CMAQ modeling system. The pollutant concentrations obtained from the MM5-CMAQ modeling system have been compared with observational data from the national air pollution monitoring network. It is found that air quality in winter in the YRD is generally worse than in summer, due mainly to unfavorable meteorological dispersion conditions. In winter, the pollution transport from Northern China to the YRD reinforces the pollution caused by large local emissions. The monthly average concentration of $\mathrm{SO}_{2}$ in the YRD is $0.026 \pm 0.011 \mathrm{mg} \mathrm{m}^{-3}$ in January and $0.017 \pm 0.009 \mathrm{mg} \mathrm{m}^{-3}$ in July. Monthly average concentrations of $\mathrm{NO}_{2}$ in the YRD in January and July are $0.021 \pm 0.009 \mathrm{mg} \mathrm{m}^{-3}$, and $0.014 \pm 0.008 \mathrm{mg} \mathrm{m}^{-3}$, respectively. The monthly average concentration of $\mathrm{PM}_{10}$ in the YRD is $0.080 \pm 0.028 \mathrm{mg} \mathrm{m}^{-3}$ in January and $0.025 \pm 0.015 \mathrm{mg} \mathrm{m}^{-3}$ in July. Visibility is also a problem, with average deciview values of $26.4 \pm 2.95 \mathrm{dcv}$ in winter and $17.6 \pm 3.3 \mathrm{dcv}$ in summer. The ozone concentration in the downtown area of a city like
\end{abstract}

Correspondence to: $\mathrm{C}$. H. Chen

(chench@saes.sh.cn)
Zhoushan can be very high, with the highest simulated value reaching $0.24 \mathrm{mg} \mathrm{m}^{-3}$. In January, the monthly average concentration of $\mathrm{O}_{3}$ in the YRD is $0.052 \pm 0.011 \mathrm{mg} \mathrm{m}^{-3}$, and $0.054 \pm 0.008 \mathrm{mg} \mathrm{m}^{-3}$ in July. Our results show that ozone and haze have become extremely important issues in the regional air quality. Thus, regional air pollution control is urgently needed to improve air quality in the YRD.

\section{Introduction}

The Yangtze River Delta (YRD), characterized by high population density and well-developed industry, is one of the largest economic regions in China. With rapid economic development in recent years and high energy consumption, air pollutant emissions are increasing steadily and the regional environment is deteriorating. Regional visibility is decreasing, ozone concentrations are increasing, and the ecological environment and health of the people are suffering. Many observational studies in the past (Chameides et al., 1999; Xu et al., 1999; Luo et al., 2000; Cheung and Wang, 2001; Wang et al., 2001a) showed that high ozone concentrations were beginning to appear in Eastern China. A project sponsored by China's National Natural Science Foundation, "The atmospheric physical and chemical process and its influence on ecosystem in the Yangtze River Delta", has conducted field surveys on air quality in the YRD, which indicate that the ozone concentration can be high in this region; the occurrence frequency of ozone concentrations higher than $0.16 \mathrm{mg} \mathrm{m}^{-3}$ reached $20 \%$ at some sites (Wang et al., 2003).

Published by Copernicus Publications on behalf of the European Geosciences Union. 
Fine particles and ozone are considered to be the most serious air pollutants of concern in China and the United States today, as well as in most metropolitan areas around the world (Streets et al., 2007). High ozone concentration at ground level increases the frequency of urban photochemical smog, accelerates the aging process of materials, threatens people's health, and causes serious damage to the ecological environment (Wang et al., 2001b). Thus, high ozone concentration has been a great concern of environmental scientists in China (Xu et al., 1999; Zhu and Xu, 1994). Fine particles not only cause worsening of regional visibility, but also seriously affect people's health. Fine particles and ozone are both formed through a serious of complex chemical reactions among primary pollutants in the air. The lifetime of ozone formed through VOC and $\mathrm{NO}_{\mathrm{x}}$ reactions is usually several days, which allows further meteorological processes to complicate the ozone formation and destruction processes (Finlayson-Pitts and Pitts, 1993). In addition, $\mathrm{NO}_{\mathrm{x}}, \mathrm{VOC}, \mathrm{SO}_{2}$, and $\mathrm{NH}_{3}$ can generate particulate matter such as $\left(\mathrm{NH}_{4}\right)_{2} \mathrm{SO}_{4}$ and $\mathrm{NH}_{4} \mathrm{NO}_{3}$ through chemical reactions. Therefore, it is difficult to assess their environmental impacts solely by experimental studies and field observations (Tesche, 1983).

To assess air quality in the YRD, the US EPA's "One Atmosphere" model, the Community Multi-scale Air Quality Modeling System (CMAQ) (Dennis et al., 1996; Byun et al., 1998; Byun and Ching, 1999), is used to simulate the chemical transport of air pollutants, driven by a new emission inventory. CMAQ is a chemical dispersion model representative of the third generation of air quality models and includes ozone, aerosols, acid deposition, visibility, and air toxics chemistry. Under a US EPA initiative, CMAQ has already been successfully transferred to the Asian situation and used to assess air quality in Beijing (An et al., 2007; Streets et al., 2007; Fu et al., 2008), the YRD (Li et al., 2008), the Pearl River Delta (PRD) (Wang et al., 2010), and across East Asia (Zhang et al., 2004, 2005, 2007; Fu et al., 2008; Lin et al., 2009). In this paper, the fifth-generation NCAR/Penn State Mesoscale Model (MM5) (Chen and Dudhia, 2001; Chen et al., 2005) is used to produce the necessary meteorological fields in 4-D data assimilation mode; CMAQ version4.4 is used for the numerical simulation of air pollutant transport and transformation in the YRD.

\section{Methodology}

\subsection{Input data}

The methodology used in this paper is to simulate the atmospheric processes over the YRD domain with MM5-CMAQ and a new emission inventory, in order to obtain a dataset with air pollutant concentrations in time and space for the simulation periods, which can then be compared with monitored concentrations. The driving meteorological inputs for CMAQ are provided by MM5, and the meteorology- chemistry interface processor (MCIP) is used to transfer MM5 output into gridded meteorological field data as the input to CMAQ. The inputs for MM5 are NCEP FNL (Final) Operational Global Analysis data, which are available on $1.0 \times 1.0$ degree grids continuously for every six hours (http://dss.ucar.edu/datasets/ds083.2/). The Carbon BondIV chemical mechanism (CB-IV) is used in the CMAQ model, which consists of 36 chemical species, 93 chemical reactions, and 11 photochemical reactions (Lamb, 1982). Geographic Information System (GIS) technology is applied in gridding the YRD regional emission inventory to the model domain.

\subsection{Model domain and simulation episodes}

The CMAQ model domain is based on a Lambert Conformal map projection, using a one-way nested mode with grid resolutions of $36 \mathrm{~km}$ (covering the whole of China), $12 \mathrm{~km}$ (covering Eastern China), and $4 \mathrm{~km}$ (covering the YRD region), as shown in Fig. 1. The MM5 domain is larger than the CMAQ domain, with three grids more than the CMAQ domain on each boundary. The mother domains for both MM5 and CMAQ are centered at $\left(110^{\circ} \mathrm{E}, 34^{\circ} \mathrm{N}\right)$. The YRD domain for CMAQ has $118 \times 136$ horizontal grid cells and includes 16 major cities, which are also shown in Fig. 1. Each "city" in the domain is a large administrative area that includes smaller cities, towns, and villages. Thus, the 16 cities together cover the majority of the YRD area. The pollution episodes chosen are 1-31 January 2004, and 1-31 July 2004, which represent winter and summer seasons, respectively. The initial conditions of CMAQ for each seasonal run are prepared by running the model five days ahead of each start date with clean initial conditions (IC). Sensitivity tests show that the influence of IC generally dissipates after about three days. The boundary condition (BC) used for the largest domain of CMAQ is clean air, while the BCs for the nested domains are extracted from the CMAQ Chemical Transport Model (CCTM) concentration files of the larger domain. Both of the two models employ 14 vertical layers of varying thickness with denser layers in the lower atmosphere to better resolve the mixing height.

\subsection{Regional emission inventory}

In this paper, a new emission inventory for the YRD was prepared, which consists of large point sources, industrial sources, mobile sources, residential sources, and biogenic sources. The basis of this inventory is a new compilation from local authorities of sources in the 16 major cities of the YRD domain.

Point sources in this inventory consist of power plants and large industrial combustion and process sources. The point source data are obtained from a national environmental statistical database provided by the Chinese Academy for Environmental Planning. Point sources are located at their exact lat/long coordinates within the domain. 


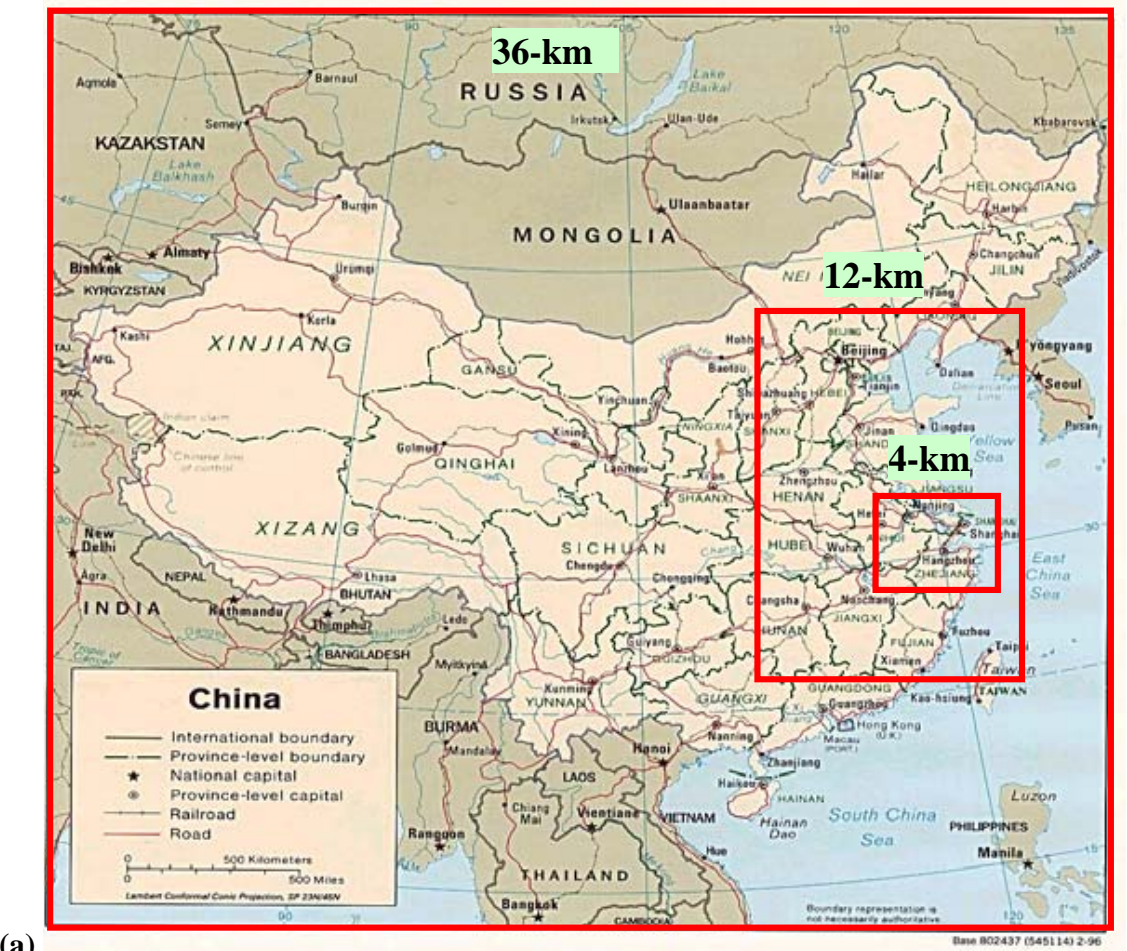

(a)

Fig. 1a. One-way nested model domain.

(b)

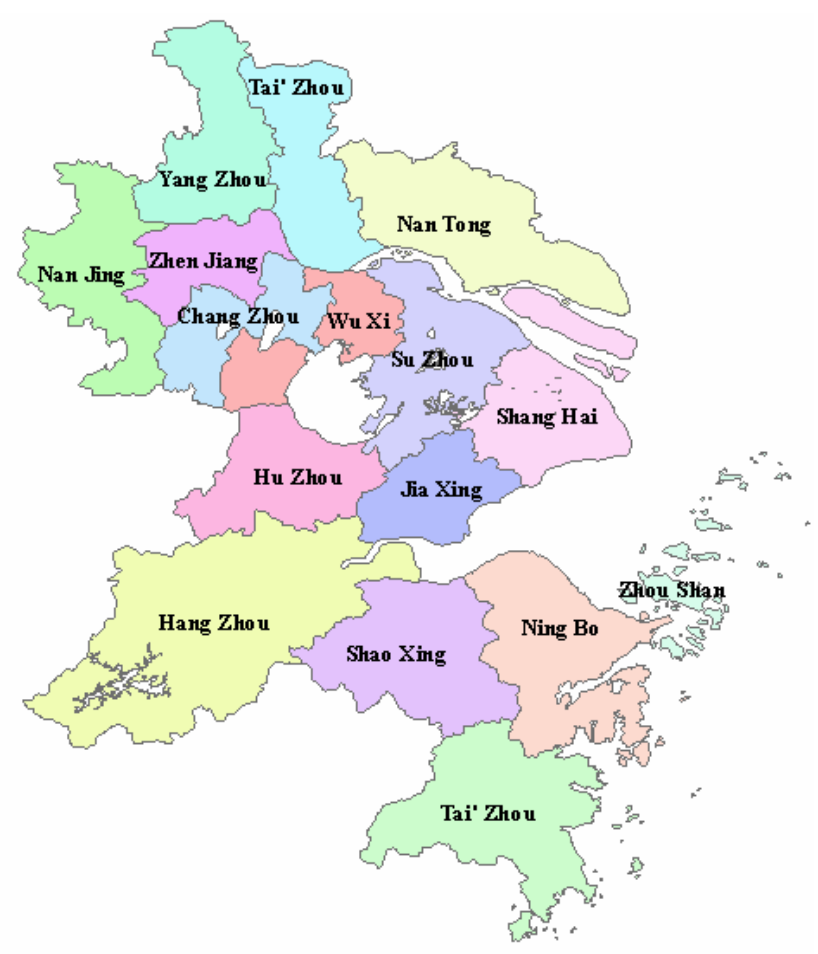

Fig. 1b. Locations of the 16 cities in the YRD.
Mobile sources consist of on-road vehicle emissions in the 16 major cities. The vehicle volume data are collected from the statistical yearbooks of Jiangsu and Zhejiang Provinces and the Shanghai Municipality (Jiangsu Statistical Yearbook, 2005; Zhejiang Statistical Yearbook, 2005; Shanghai Statistical Yearbook, 2005).

Areas sources in this paper include fugitive emissions from industrial activity and residential fuel combustion. Residential emissions are calculated based on the consumption of coal, LPG, coal gas, and natural gas in 2004, as obtained from the statistical yearbooks of the 16 cities in the YRD.

For biogenic VOC emissions, this study uses the natural VOC emission inventory of the GEIA Global Emissions Inventory Activity 1990 (http://geiacenter.org). In July, total biogenic VOC emissions in Shanghai were 3,286 tons, taking a share of $23 \%$ of the total biogenic emissions in the YRD. The GEIA emissions may be outdated due to rapid development of the YRD region and consequent changes in the natural ecosystem, and we are considering to update these emissions in future work.

Emission factor is an important element that influences the estimation of emission inventory. Supporting data on emission factors and activity data were assembled from related studies. Emission factors in this study are mainly referred to widely accepted studies or calculated based on related parameters. The $\mathrm{SO}_{2}$ emissions from major pollutant sources are calculated based on fuel consumption and sulphur content. Results have been compared and verified with 

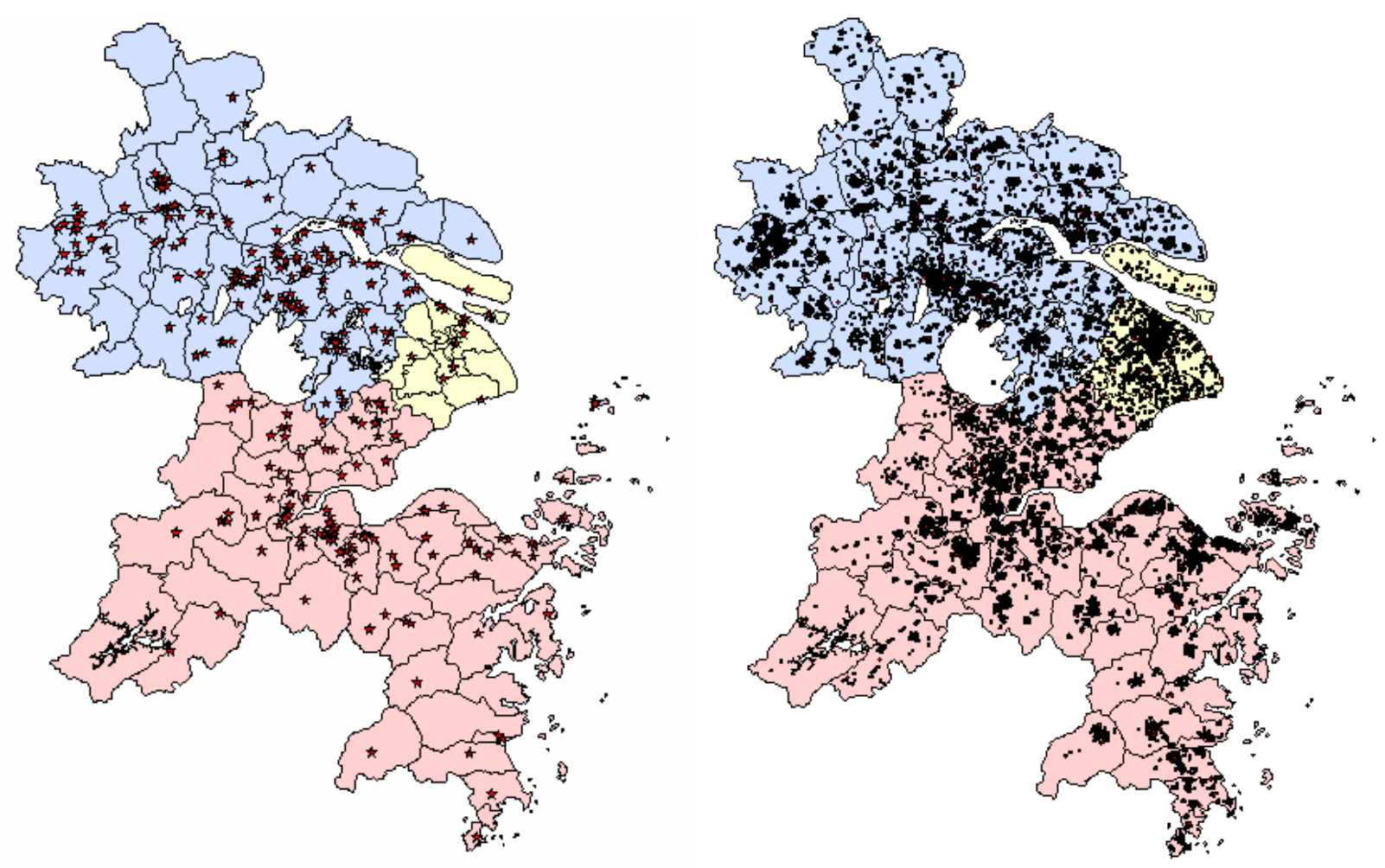

Fig. 2. Distribution of point sources in the YRD (top: power plants; bottom: industrial point sources); Jiangsu Province is shown in blue, Zhejiang Province in pink, and the Shanghai Municipality in yellow.

other environmental statistical data. Emission factors and fuel parameters are mainly derived from national literature (Hu, 1990; MEP, 1996), including "User's Guide on the Production and Emission Factors of Industrial Pollutants" and "Environmental Protection Data Manual". Related data have been widely used in other studies (Streets et al., 2000; Kuang et al., 2001; Di et al., 2005). Emission factors of other pollutants like $\mathrm{NO}_{\mathrm{x}}$ and $\mathrm{CO}$ are obtained through calculation or referred to related studies (Fang et al., 1985; Hu, 1990; Kato et al., 1992; Akimoto et al., 1994; MEP, 1996; Streets et al., 2000, 2001, 2003a, b). Emission factors of VOC, $\mathrm{NH}_{3}$, $\mathrm{PM}_{10}$ and $\mathrm{PM}_{2.5}$ are mainly obtained through literature survey (Kato et al., 1992; Akimoto et al., 1994; Streets et al., 2000, 2001, 2003a,b; USEPA, 2006). Currently, we are lacking measurement data in the YRD to verify those emission factors, which could likely be taken into consideration in future studies.

The newly calculated emissions for the 16 cities in the YRD are then inserted into the regional East Asian emission inventory provided by TRACE-P (Streets et al., 2003a,b; Fu et al., 2008), which provides emissions data for the remaining parts of the domain. The TRACE-P emission inventory has been described and demonstrated to be reliable for China in previous studies (Streets et al., 2003a,b; Carmichael et al., 2003).

\section{Results and discussion}

\subsection{Regional emission inventory for the YRD}

\subsubsection{Point sources}

There were 378 power plants in the 16 cities of the YRD in 2004. In addition, there were 9793 major industrial sources, among which there were 4381 in Jiangsu Province (44.7\%), 3864 in Zhejiang Province (39.5\%), and 1548 in Shanghai Municipality (15.8\%). Figure 2 shows the distribution of these point sources in the YRD. This is the first time that a comprehensive allocation of emissions to major point sources in the YRD has been developed. In 2004, the emissions of $\mathrm{SO}_{2}, \mathrm{NO}_{\mathrm{x}}, \mathrm{CO}, \mathrm{PM}_{10}, \mathrm{PM}_{2.5}$, and $\mathrm{VOC}$ in the power-plant sector were 1381, 727, 157, 660, 346, and $7 \mathrm{Gg}$, respectively. Emissions from power plants in Jiangsu Province are the highest, representing shares of $48 \%, 48 \%$, $53 \%, 60 \%, 60 \%$, and $51 \%$, respectively, in the power-plant emissions of the pollutants listed above. Although there are only 19 power plants in Shanghai Municipality, they tend to be large ones, with shares of $18 \%, 19 \%, 20 \%, 7 \%, 7 \%$, and $20 \%$, respectively.

Emissions of $\mathrm{SO}_{2}, \mathrm{NO}_{\mathrm{x}}, \mathrm{CO}, \mathrm{PM}_{10}, \mathrm{PM}_{2.5}$, and VOC from fuel combustion in the industrial sector are $311,168,38$, 341,140 , and $2 \mathrm{Gg}$, respectively. The emissions from fuel 


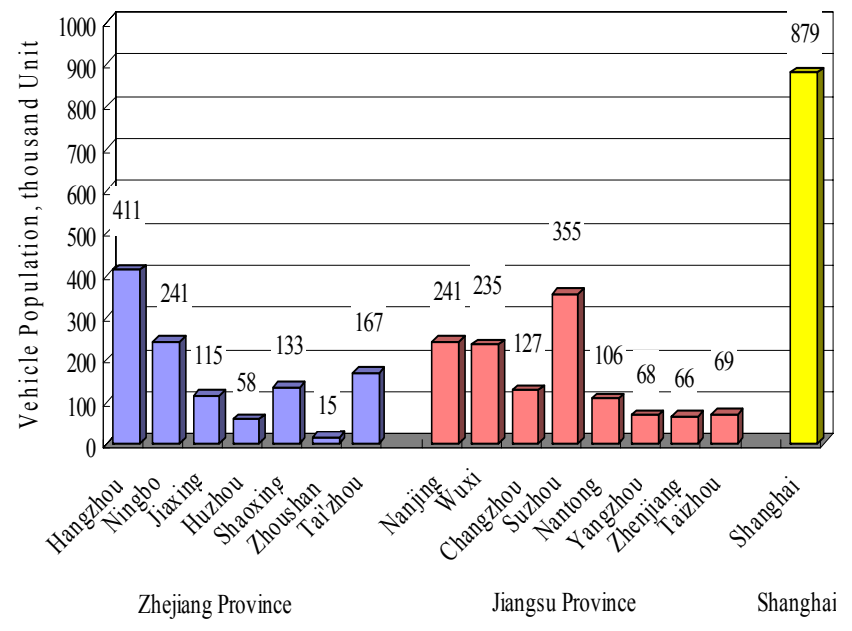

Fig. 3. Vehicle stocks (without motorcycles) of the 16 major cities of the YRD in 2004.

combustion in industry are highest in Jiangsu Province with shares of $54 \%, 38 \%, 34 \%, 49 \%, 50 \%$, and $31 \%$, respectively. Process emissions of $\mathrm{SO}_{2}, \mathrm{NO}_{\mathrm{x}}, \mathrm{CO}, \mathrm{PM}_{10}, \mathrm{PM}_{2.5}, \mathrm{VOC}$, and $\mathrm{NH}_{3}$ from the industrial sector are 63, 21, 378, 603, 335, 284 , and $31 \mathrm{Gg}$, respectively. Jiangsu Province is again the highest emitter, with shares of 58\%, 43\%, 58\%, 41\%, 42\%, $46 \%$, and $52 \%$, respectively.

\subsubsection{Mobile sources}

Figure 3 shows the vehicle stocks in each of the major cities of the YRD in 2004. There were 3286000 cars in the 16 cities, among which Jiangsu Province contains 1270000 , Zhejiang Province contains 1141000 , and Shanghai contains 878 000. Among all the 16 cities, Shanghai, Hangzhou, Suzhou, Ningbo, and Nanjing contain the largest vehicle stocks, with shares of $26 \%, 12 \%, 11 \%, 8 \%$, and $8 \%$, respectively. In addition, there were 9798000 motorcycles and 7266000 light-duty motorcycles in the major cities of the YRD in 2004. Jiangsu, Zhejiang, and Shanghai contain $59 \%, 40 \%$, and $1 \%$ of the total motorcycles and $12 \%, 74 \%$, and $14 \%$ of the light-duty motorcycles, respectively.

The compositions of the vehicle fleets are very different between Shanghai Municipality and the two neighboring provinces. Figure 4 shows the vehicle stocks by category in the two provinces and Shanghai. In Shanghai, light-duty cars represent $30 \%$ of total vehicles; while motorcycles (including light-duty motorcycles) are a major vehicle category in Jiangsu and Zhejiang Provinces, with shares of $80 \%$ and $73 \%$, respectively.

Based on these vehicle stock data and local emission factors, the mobile source emissions of $\mathrm{CO}, \mathrm{VOC}, \mathrm{NO}_{\mathrm{x}}, \mathrm{PM}_{2.5}$, and $\mathrm{SO}_{2}$ in the YRD in 2004 were estimated to be 2302, 446, 358, 62, and $11 \mathrm{Gg}$, respectively. Regional shares for each of the species were for Jiangsu Province 49\%, 50\%, 46\%, $50 \%$, and 44\%, for Zhejiang Province 28\%, 30\%, 29\%, 29\%,

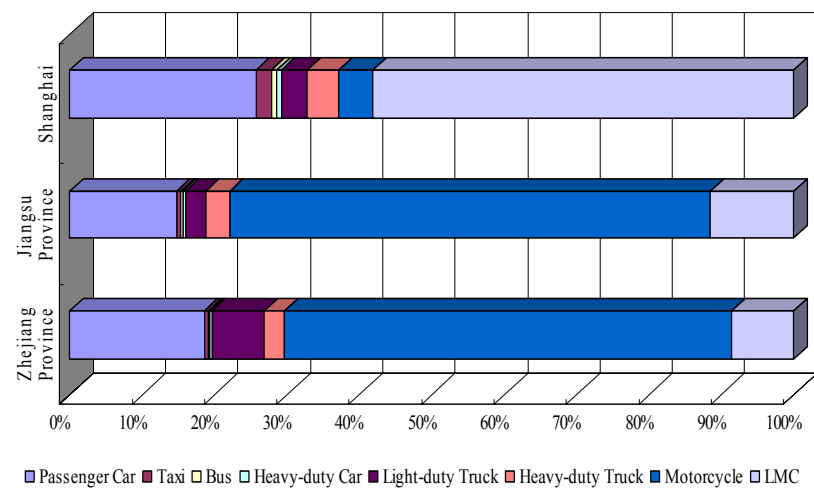

Fig. 4. Vehicle categories in the two provinces and Shanghai in 2004.

and $29 \%$, and for Shanghai 24\%, 20\%, 25\%, 22\%, and $28 \%$. Since Shanghai is a megacity with large numbers of vehicles, it has a larger share of mobile-source emissions than stationary sources. Since the vehicle mileage of heavy-duty trucks in Jiangsu Province is very high, the $\mathrm{NO}_{\mathrm{x}}$ and $\mathrm{PM}_{10}$ emissions in the cities of Jiangsu Province are high. In addition, the large stocks of motorcycles and light-duty motorcycles are major sources of $\mathrm{CO}$ and VOC emissions in the YRD.

\subsubsection{Area sources}

Emissions from residential fuel combustion are calculated directly from fuel-use data for each of the cities in the region. Table 1 shows the residential fuel consumption in the cities of the YRD in 2004, as well as the populations of the cities. Though coal and LPG are used extensively in Jiangsu Province and Zhejiang Province, gas - both coal gas and natural gas - is preferred in Shanghai.

Fugitive emissions from industrial activity are calculated based on the consumption of coal and fuel oil in the YRD after energy consumption in the power plant, industry, transportation, and residential sectors is eliminated. Results show that in 2004, the emissions of $\mathrm{SO}_{2}, \mathrm{NO}_{\mathrm{x}}, \mathrm{CO}, \mathrm{PM}_{10}, \mathrm{PM}_{2.5}$, and VOC from residential fuel combustion were 16.4, 8.6, 17.6, 2.9, 1.7, and 1.0 Gg, respectively. Emissions of $\mathrm{SO}_{2}$, $\mathrm{NO}_{\mathrm{x}}, \mathrm{CO}, \mathrm{PM}_{10}, \mathrm{PM}_{2.5}, \mathrm{VOC}$, and $\mathrm{NH}_{3}$ from fugitive emissions of industry were $288,114,257,28,19,26$ and $1 \mathrm{Gg}$, respectively.

\subsection{Model performance}

\subsubsection{Observational sites used to compare against MM5-CMAQ model results}

In this paper we use selected hourly concentration data for $\mathrm{SO}_{2}, \mathrm{NO}_{2}, \mathrm{PM}_{10}$, and $\mathrm{O}_{3}$ measured during the periods 1120 January 2004, and 11-20 July 2004, at each of the 43 national observational sites located in the YRD to assess the performance of the model. The locations of the measurement sites are shown in Fig. 5. 
Table 1. Residential fuel consumption in the YRD in 2004.

\begin{tabular}{llccccc}
\hline $\begin{array}{l}\text { Province or } \\
\text { municipality }\end{array}$ & City & $\begin{array}{c}\text { Population } \\
\text { (millions) }\end{array}$ & $\begin{array}{c}\text { Coal } \\
\left(10^{4} \mathrm{t}\right)\end{array}$ & $\begin{array}{c}\text { LPG } \\
\left(10^{4} \mathrm{t}\right)\end{array}$ & $\begin{array}{c}\text { Coal gas } \\
\left(10^{6} \mathrm{~m}^{3}\right)\end{array}$ & $\begin{array}{c}\text { Nat gas } \\
\left(10^{6} \mathrm{~m}^{3}\right)\end{array}$ \\
\hline & Nanjing & 5.8 & 7.0 & 9.8 & 76.9 & 3.1 \\
& Wuxi & 4.5 & 5.6 & 3.7 & 29.2 & 1.2 \\
Jiangsu & Changzhou & 3.5 & 4.3 & 4.9 & 38.0 & 1.5 \\
Province & Suzhou & 6.0 & 7.4 & 7.1 & 55.4 & 2.3 \\
& Nantong & 7.7 & 9.7 & 5.6 & 44.2 & 1.8 \\
& Yangzhou & 4.5 & 5.8 & 1.5 & 11.4 & 0.5 \\
& Zhenjiang & 2.7 & 3.3 & 3.6 & 28.2 & 1.1 \\
& Taizhou & 5.0 & 6.2 & 5.2 & 40.8 & 1.7 \\
& Total & $\mathbf{3 9 . 8}$ & $\mathbf{4 9 . 3}$ & $\mathbf{4 1 . 4}$ & $\mathbf{3 2 4 . 1}$ & $\mathbf{1 3 . 2}$ \\
\hline \multirow{6}{*}{ Zhejiang } & Hangzhou & 6.5 & 8.6 & 23.0 & 12.7 & 0.0 \\
Province & Ningbo & 5.5 & 6.6 & 16.2 & 7.9 & 0.0 \\
& Jiaxing & 3.3 & 4.0 & 9.9 & 4.9 & 0.0 \\
& Huzhou & 2.6 & 3.0 & 7.2 & 3.4 & 0.0 \\
& Shaoxing & 4.3 & 5.0 & 11.8 & 5.4 & 0.0 \\
& Zhoushan & 1.0 & 1.2 & 3.0 & 1.6 & 0.0 \\
& Taizhou & 5.6 & 5.9 & 12.0 & 4.3 & 0.0 \\
& Total & $\mathbf{2 8 . 8}$ & $\mathbf{3 4 . 4}$ & $\mathbf{8 3 . 0}$ & $\mathbf{4 0 . 3}$ & $\mathbf{0 . 0}$ \\
\hline Shanghai Municipality & $\mathbf{1 3 . 5}$ & $\mathbf{8 0 . 6}$ & $\mathbf{2 0 . 4}$ & $\mathbf{1 2 2 3 . 0}$ & $\mathbf{1 9 7 . 0}$ \\
\hline
\end{tabular}

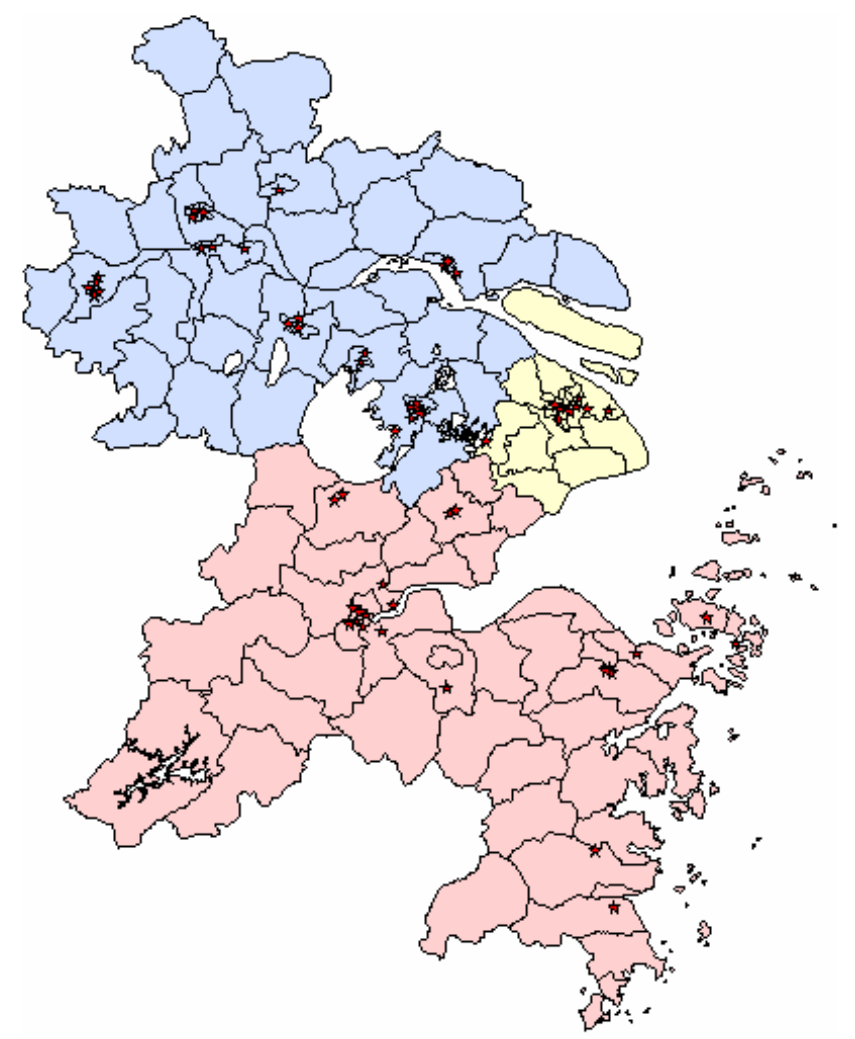

Fig. 5. Locations of the national observational sites used in the model performance assessment.

\subsubsection{MM5 performance}

The daily average wind speed and temperature data observed on the site of Baoshan in January and July 2004 in Shanghai are compared with the MM5 results, as shown in Figs. 6 and 7. Comparisons between the figures show that the parameters adopted in MM5 could basically reflect the variations of the wind speed and temperature in the region. MM5 correctly reproduces the major patterns of the observed wind flow and that wind speed is within acceptable error limits.

To further study the MM5 performance, several statistical measures including the Bias Error (B), the Root Mean Square Error (RMSE), and the index of agreement (IOA) are calculated as part of the meteorological model evaluation. These measures are calculated for daily average wind speed and temperature at the surface observational site and the $10-\mathrm{m}$ height model results.

Bias Error (B) is calculated as the mean difference in prediction-observation pairings with valid data within a given analysis region and for a given time period (hourly or daily), as shown by Eq. (5):

$\mathrm{B}=\frac{1}{I J} \sum_{j=1}^{J} \sum_{i=1}^{I}\left(P_{j}^{i}-O_{j}^{i}\right)$

The RMSE is calculated as the square root of the mean squared difference in prediction-observation pairings with valid data within a given analysis region and for a given 

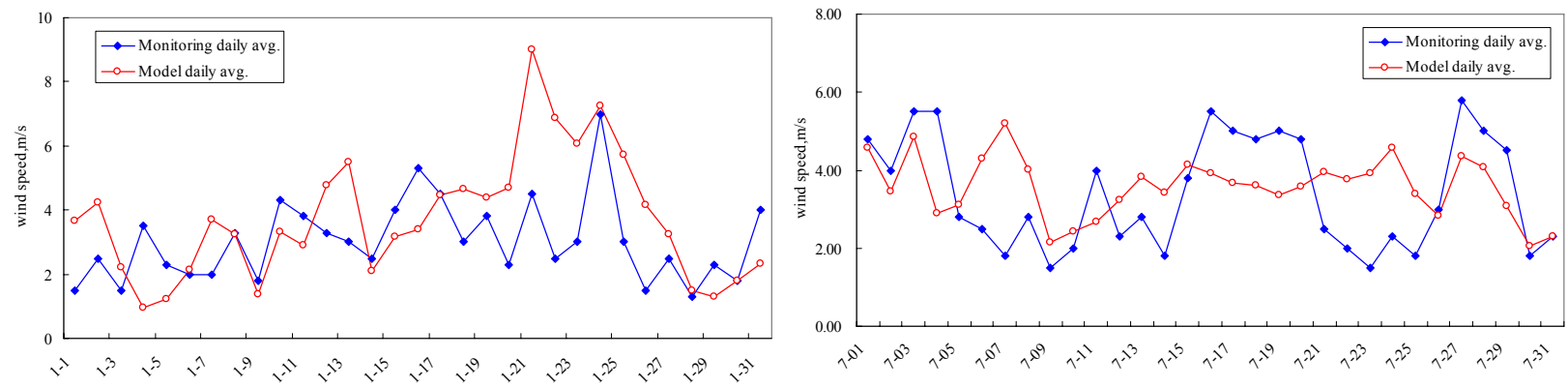

Fig. 6. Wind speed comparison between observed and prediction data for January and July 2004.
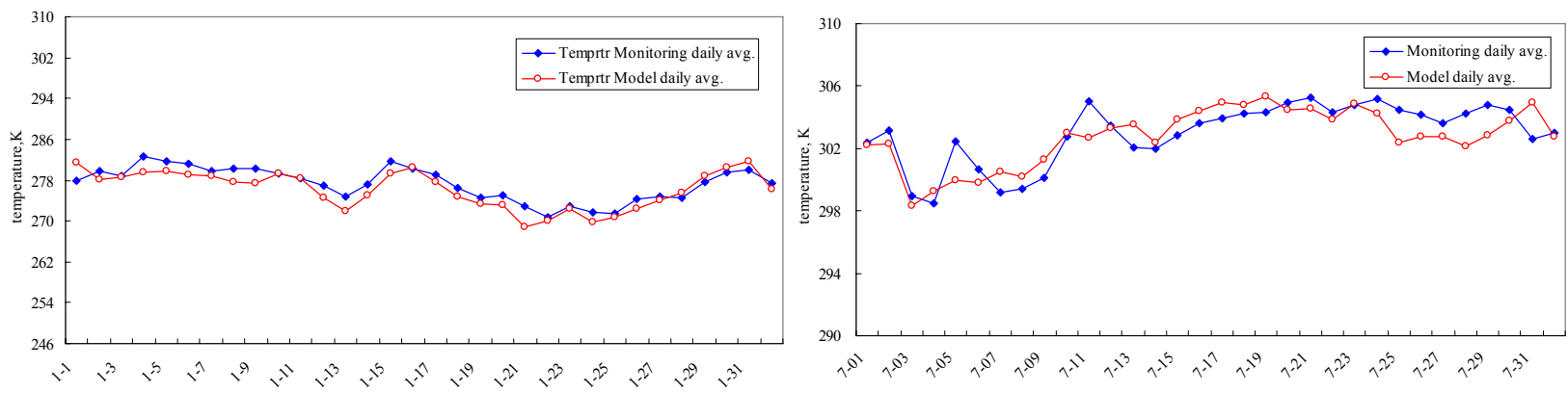

Fig. 7. Temperature comparison between observed and prediction data for January and July 2004.

time period (hourly or daily). It is a good overall measure of model performance, which is calculated by Eq. (2):

$\operatorname{RMSE}=\left[\frac{1}{\mathrm{IJ}} \sum_{j=1}^{\mathrm{J}} \sum_{i=1}^{I}\left(\mathrm{P}_{j}^{i}-O_{j}^{i}\right)^{2}\right]^{1 / 2}$

In Eqs. (5) and (2), Oij is the individual observed quantity at site $i$ and time $j$, and the summations are over all sites (I) and over time periods $(\mathrm{J}) . \mathrm{P}_{j}^{i}$ is the individual predicted quantity at site $i$ and time $j$.

The index of agreement is calculated by Eq. (3):

$\mathrm{I}=1-\frac{\sum_{i=1}^{N}\left(p_{i}-o_{i}\right)^{2}}{\sum_{i=1}^{N}\left(\left|p_{i}-\bar{o}\right|+\left|o_{i}-\bar{o}\right|\right)^{2}}$

where $\bar{o}$ denotes the average observed concentration and a value of 1 indicates perfect agreement between predicted and observed values.

Statistical results between MM5 model and observation data are shown in Table 2. Table 2 demonstrates that the MM5 performance is reliable.

\subsubsection{CMAQ performance test results and analysis}

Figures 8-11 show comparisons between the observed and modeled $\mathrm{SO}_{2}, \mathrm{NO}_{2}$ and $\mathrm{PM}_{10}$ concentrations at the observational sites during 11-20 January and 11-20 July 2004.
Table 2. Statistical results between MM5 model and observation data at Shanghai Baoshan Station.

\begin{tabular}{llrrr}
\hline Time & Parameter & Bias & RMSE & IOA \\
\hline Jan 2004 & Wind Speed & -0.04 & 1.48 & 0.66 \\
& Temperature & -1.06 & 1.90 & 0.92 \\
\hline \multirow{2}{*}{ Jul 2004 } & Wind Speed & 0.17 & 1.45 & 0.53 \\
& Temperature & -0.20 & 1.24 & 0.89 \\
\hline
\end{tabular}

The finest grid resolution is $4 \mathrm{~km} \times 4 \mathrm{~km}$, with the grid area of $16 \mathrm{~km}^{2}$. Some observational sites are quite close and are within one grid cell, as is shown in Fig. 5. Thus, we give the monitoring max, min and average values of the monitoring data at several sites within one grid, to be compared with the model result. The average model result means the data of the specific grid that contains those observational sites. And the vertical layer of the model result is only the surface layer.

\section{Sulfur dioxide}

Figure 8 shows a comparison between the observed and modeled $\mathrm{SO}_{2}$ concentrations at the Nantong, Shanghai, and Hangzhou observational sites during 11-20 January and 1120 July 2004. It is to be expected that CMAQ would perform relatively well at predicting $\mathrm{SO}_{2}$ concentrations, because the 

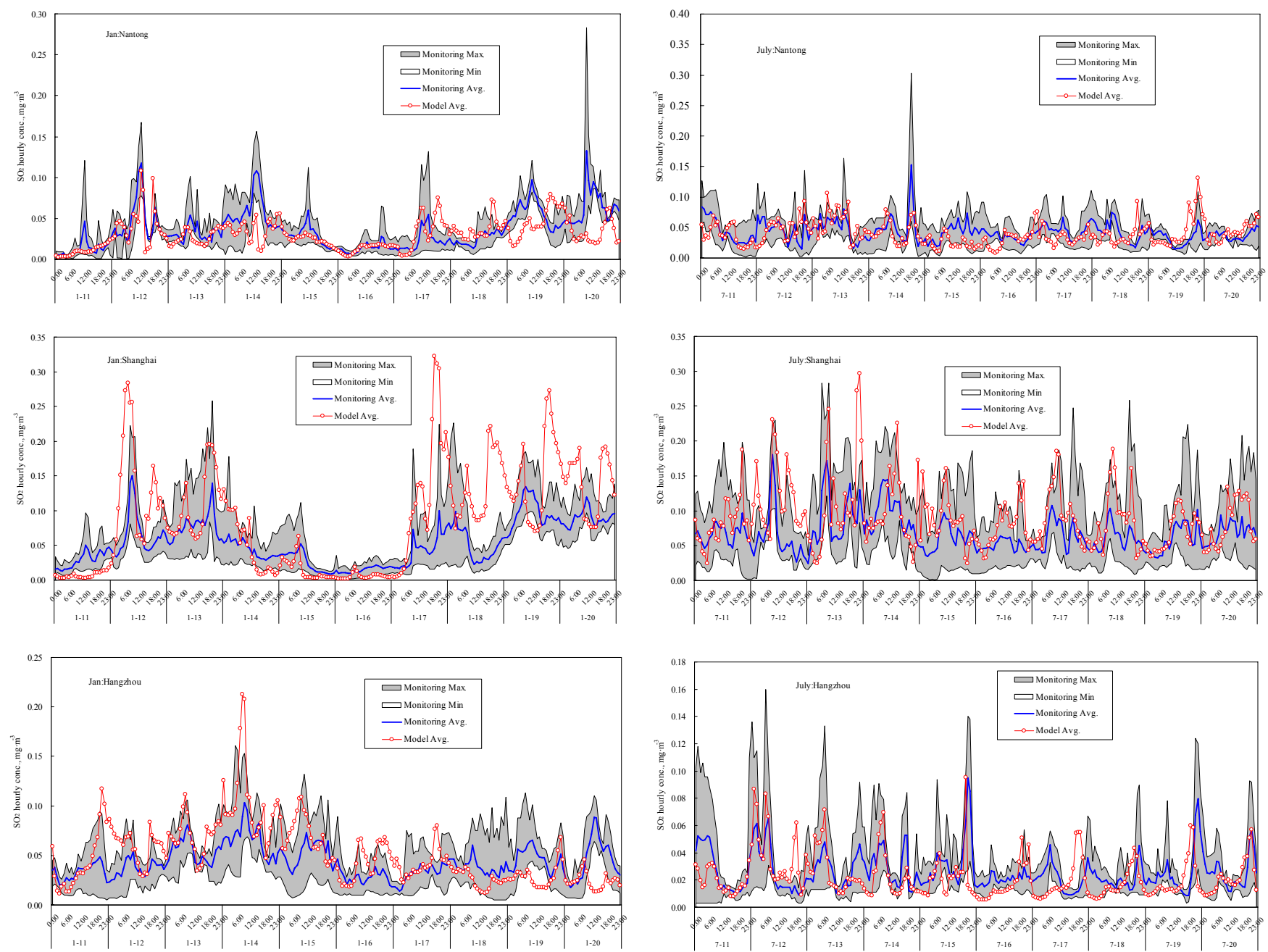

Fig. 8. Comparison of CMAQ model simulations for $\mathrm{SO}_{2}$ concentrations against observations.

emission inventory is most reliable for $\mathrm{SO}_{2}$ emissions that do not involve large contributions from small, dispersed sources, and because the chemistry and transport of $\mathrm{SO}_{2}$ has been extensively studied for many years. Results show that CMAQ reproduces the variation trends of this pollutant well at each site. This provides additional confidence in the emission inventory of $\mathrm{SO}_{2}$ in the YRD in 2004 and confirms that the meteorological fields used and the assumptions made in the CMAQ model reflect the true $\mathrm{SO}_{2}$ pollution situation in the YRD.

\section{Nitrogen dioxide}

Figure 9 shows the comparison between model results and observational data of $\mathrm{NO}_{2}$ hourly concentrations at Nanjing, Shanghai, and Hangzhou monitoring sites during 1120 January and 11-20 July 2004. Results show that CMAQ can reproduce the variation trends of the pollutant concentrations. The modeling results for Nanjing, Shanghai, and
Hangzhou are good and reflect the actual $\mathrm{NO}_{2}$ pollution status in these cities. However, The $\mathrm{NO}_{\mathrm{x}}$ emission sources include not only power plants, industrial boilers and kilns, but also the emissions from mobile sources and residential combustion. Therefore, their magnitude and spatial distribution are more uncertain. In addition, of course, the local chemistry of $\mathrm{NO}_{\mathrm{x}}$ emissions conversion is more complex than that of primary $\mathrm{SO}_{2}$ emissions. $\mathrm{NO}_{\mathrm{x}}$ conversion may be affected by possible underestimation of VOC emissions; some fugitive VOC emissions such as painting and evaporative emissions at gasoline refilling stations are not included in the inventory. In addition, the estimation of $\mathrm{NH}_{3}$ emissions in the 16 city areas may be lower than in reality, because $\mathrm{NH}_{3}$ emissions from fertilizer usage and livestock breeding in rural areas can be significant but are not included in the inventory. Thus, the transformation from $\mathrm{NO}_{\mathrm{x}}, \mathrm{VOC}$, and $\mathrm{NH}_{3}$ to particles may be underestimated in the model, which causes uncertainty in the $\mathrm{NO}_{2}$ modeling result. 

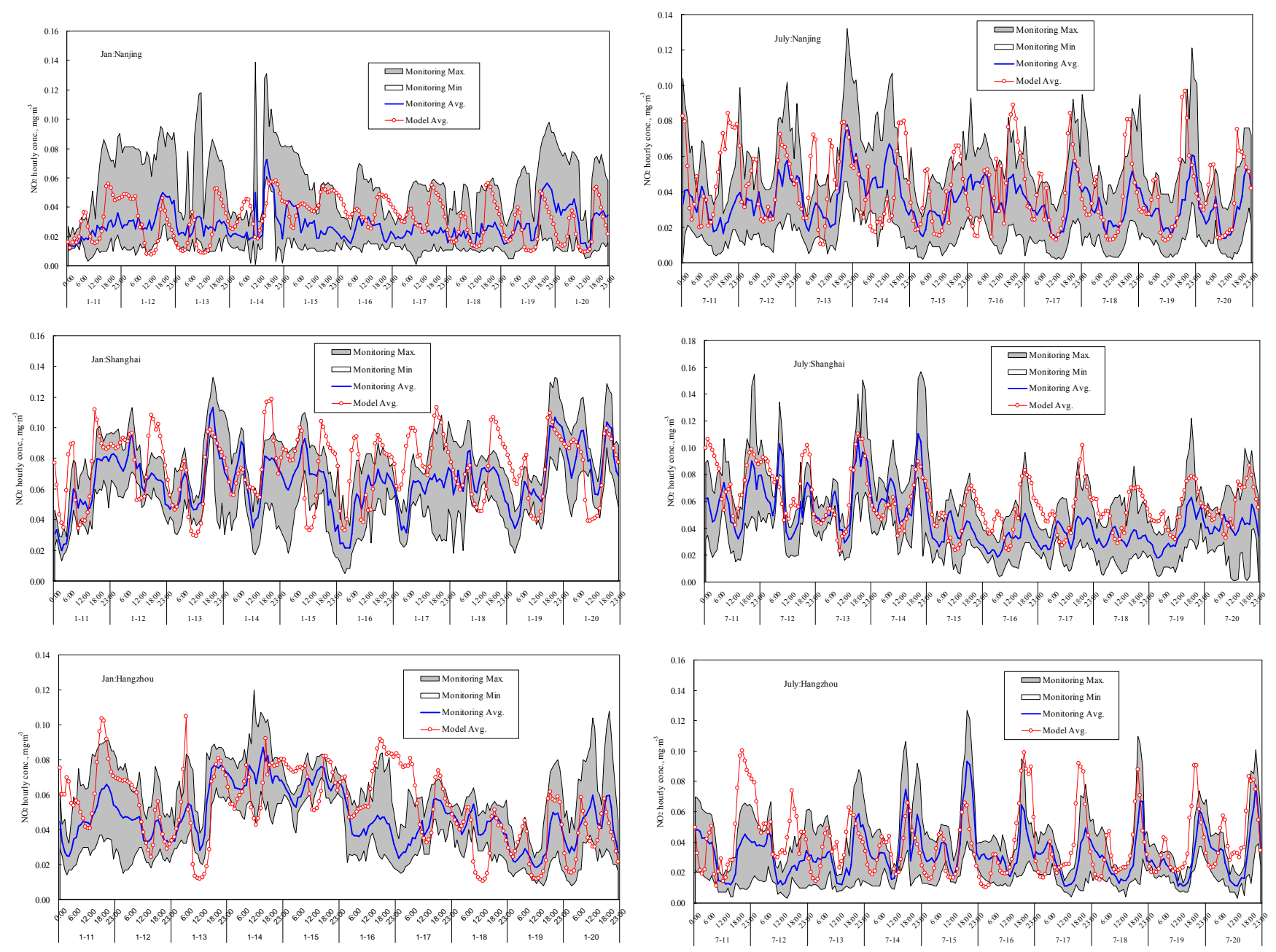

Fig. 9. Comparison of CMAQ model simulations for $\mathrm{NO}_{2}$ concentrations against observations.

\section{Particulate matter (PM)}

Influenced heavily by meteorological conditions, $\mathrm{PM}_{10}$ concentrations are quite significant in winter time. Figure 10 shows a comparison between model results and observational data of $\mathrm{PM}_{10}$ hourly concentrations at Nantong, Ningbo, Jiaxing, and Huzhou monitoring sites during 11-20 January and 11-20 July 2004. Results show that CMAQ can reflect the trends of $\mathrm{PM}_{10}$ in July, while in January the model tends to underestimate the $\mathrm{PM}_{10}$ concentrations. There are four possible reasons. First, the $\mathrm{PM}_{10}$ emission inventory for the region may be underestimated, since fugitive dust emissions from construction sites, road transportation, coal stockpiles, etc., are not included. Second, since $\mathrm{NH}_{3}$ emissions from rural areas are not considered, the transformation from $\mathrm{NO}_{\mathrm{x}}$ and $\mathrm{NH}_{3}$ to particles is weaker than expected. Third, VOC emissions in this study may be underestimated since there are some source types that are not included in the emission inventory; thus, fine particles formed through complex chemical reactions involving $\mathrm{NO}_{\mathrm{x}}$, VOC, etc., may be underesti- mated. Last but not least, on the occasions of high pollution episodes, particularly in winter, the dominant wind is from a northerly direction and carries pollutants from north to south and affects the regional air quality in the YRD. In such cases, especially when there are dust storms in Northern China, our local emission inventory and even the regional TRACE-P inventory may not include all PM emissions and the modeled results may be lower than the observed ones.

\section{Ozone}

Hourly $\mathrm{O}_{3}$ concentration data were only collected for Nanjing in January 2004 and for Shanghai in July 2004. Therefore, the observational data that are available for model testing are limited. Figure 11 shows the comparisons between model results and available monitoring data for hourly $\mathrm{O}_{3}$ concentrations in January and July. Results show that CMAQ can reflect the variation trends of the pollutant. Specifically, the model gives reliable results for the summer case. Figure 11 shows that the model reproduces the daily change of 

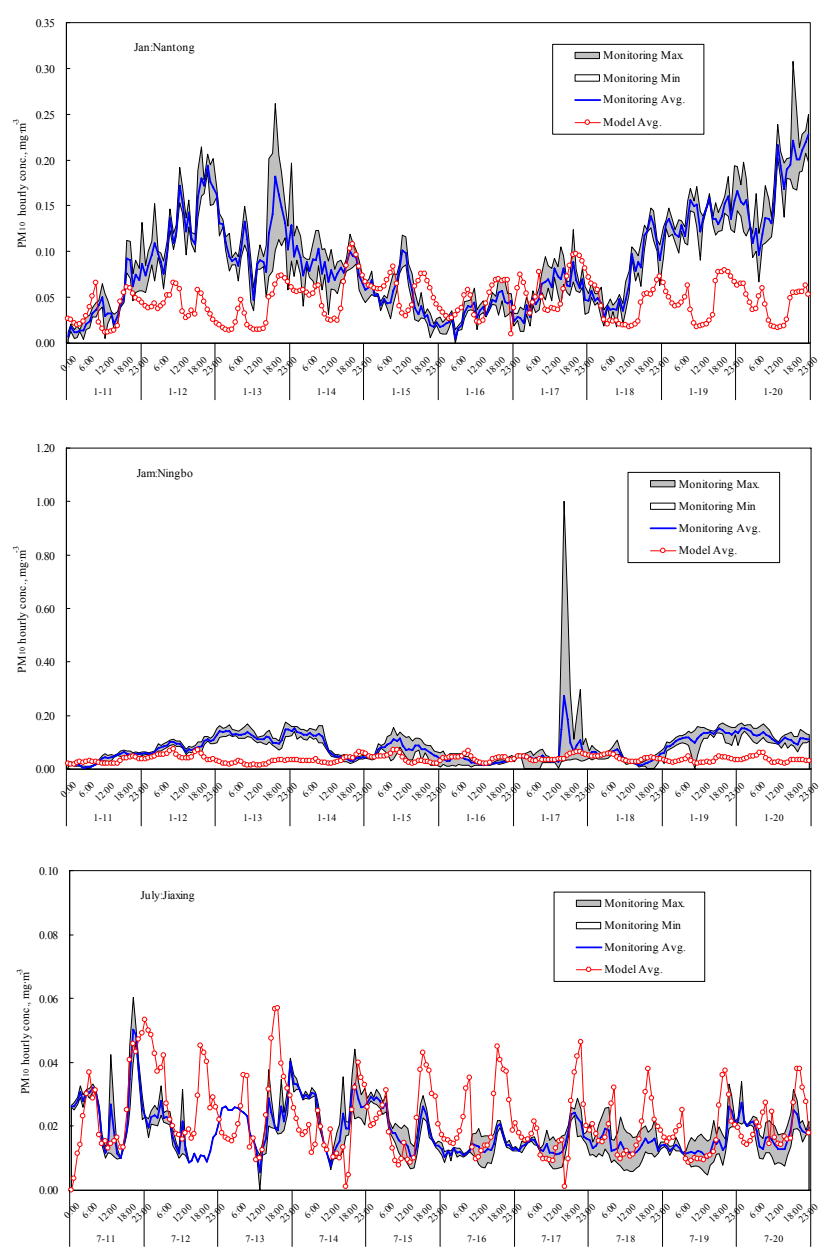

Fig. 10. Comparison of CMAQ model simulations for $\mathrm{PM}_{10}$ concentrations against observations.

$\mathrm{O}_{3}$ concentration. With increase of solar radiation early in the day, the $\mathrm{O}_{3}$ concentration rises; while in the afternoon, with decrease of radiation, the $\mathrm{O}_{3}$ concentration gradually declines. The ozone concentration is influenced by emissions of precursors like $\mathrm{NO}_{\mathrm{x}}$ and VOC, VOC speciation, and the temporal profiles of the emissions. The VOC speciation is compiled based on a literature survey (Streets et al., 2003a), but is known to be based largely on western sources, rather than Chinese sources, most of which have never been measured. The modeled $\mathrm{O}_{3}$ concentration at midnight is not as low as expected, which is due to the PBL height simulation by MM5. In this paper, the MRF parameters are adopted in MM5 modeling, which usually gives high PBL height in daytime and low PBL at night (Han et al., 2008). This systematic error tends to result in underestimation of ozone concentrations in the daytime and overestimation at nighttime. Although the MRF parameter could not give a satisfactory result in the PBL prediction, it is good in the simulation of other meteorological elements like wind speed and temperature. Thus, it is chosen in this study.
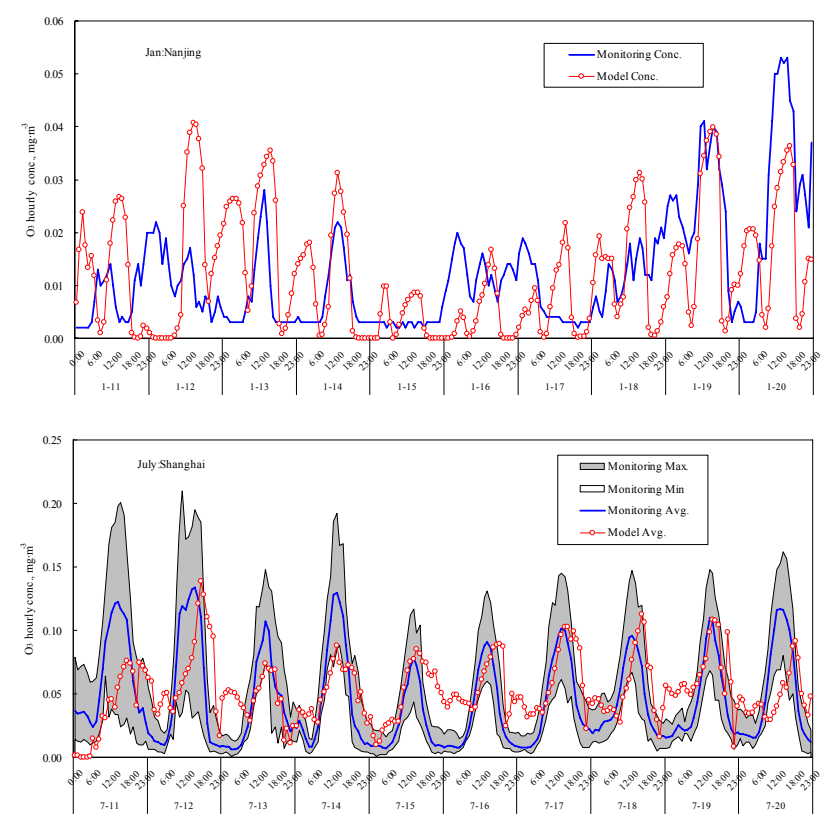

Fig. 11. Comparison of CMAQ model simulations for $\mathrm{O}_{3}$ concentrations against observations.

\section{Factor 2 analyses}

Factor 2 analysis is one of the methods commonly used to check whether the air quality model results are acceptable. Factor 2 calculates the percentages of the ratios of model value to observational value that lie between 0.5 and 2 . The calculation formula is shown in Eq. (4):

$R=\frac{N_{[1 / 2,2]}}{N_{t}}$

where $R$ is the percentage of the ratios between 0.5 and 2 ; $N_{[1 / 2,2]}$ is the number of the ratios between 0.5 and 2; and $N_{t}$ is the total number of comparison points.

The larger the $R$ value, the better the model performs. $R=100 \%$ means the model performance is perfect. Figure 12 shows the factor 2 analysis results for $\mathrm{SO}_{2}, \mathrm{NO}_{2}$, and $\mathrm{PM}_{10}$. Results show that in January, 59\%, 80\%, and 51\% of the ratios between model and observational data for $\mathrm{SO}_{2}$, $\mathrm{NO}_{2}$, and $\mathrm{PM}_{10}$, respectively, are within the factor 2 ranges. For the month of July, $75 \%, 81 \%$, and $73 \%$ of the ratios of $\mathrm{SO}_{2}, \mathrm{NO}_{2}$, and $\mathrm{PM}_{10}$, respectively, are within the factor 2 range. Generally speaking, the model performs quite well in the prediction of $\mathrm{SO}_{2}, \mathrm{NO}_{2}$, and $\mathrm{PM}_{10}$. However, for ozone, there are only $32 \%$ and $50 \%$ of the results in winter and summer, respectively, within the factor 2 range. As shown in the figure, there are many points with modeled data higher than the observed ones, which is possibly due to the low PBL height at nighttime obtained by MM5, as mentioned above. 

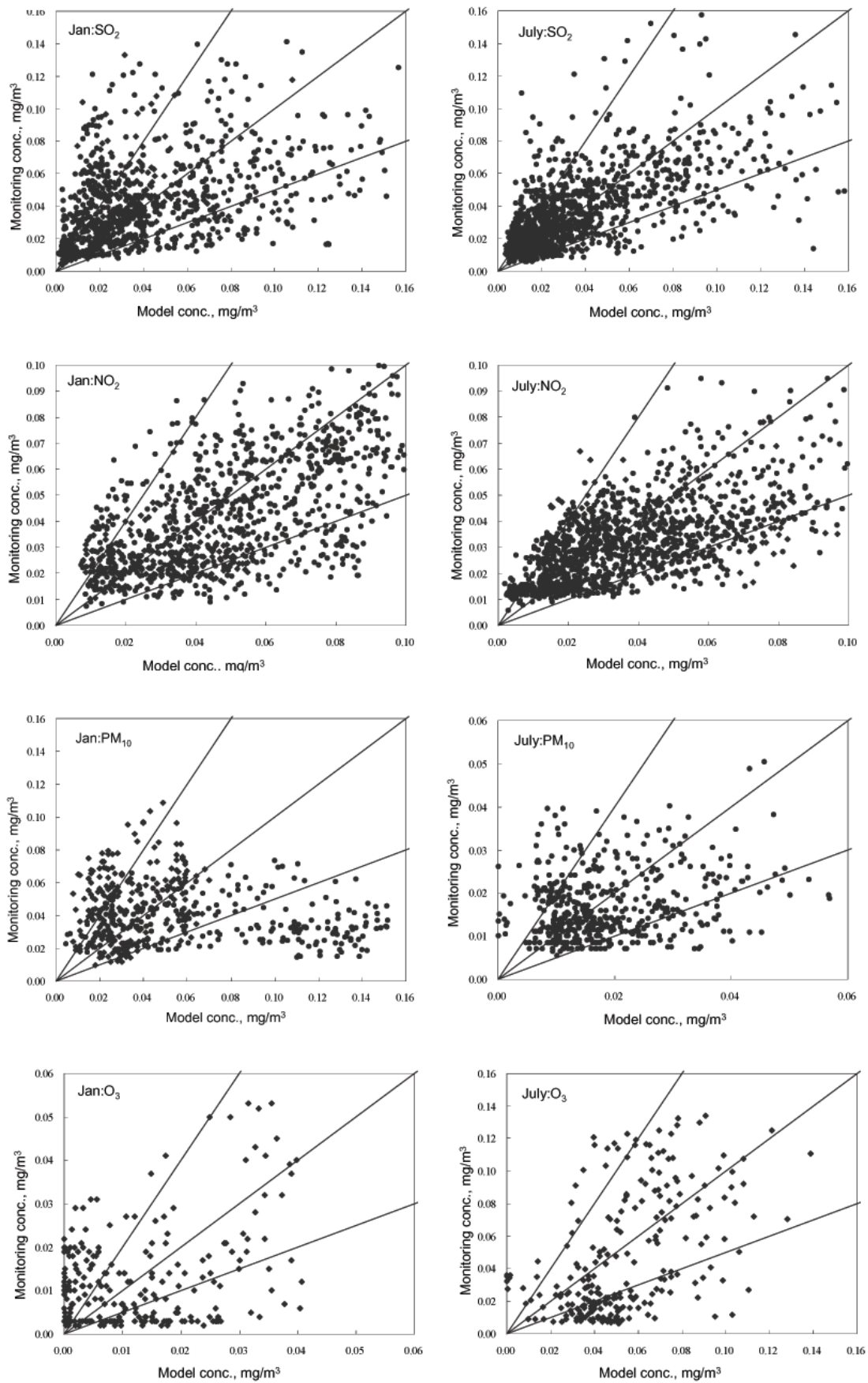

Fig. 12. Factor 2 analyses of model results (January and July) for $\mathrm{SO}_{2}, \mathrm{NO}_{2}, \mathrm{PM}_{10}$, and $\mathrm{O}_{3}$.

\subsubsection{Statistical analysis of the performance results}

To further study the model capability and applicability in the model domain, the following statistical measures were applied: normalized bias, index of agreement, correlation coefficient, and factor of two. The normalized bias is calculated by Eq. (5):
Bias $=\frac{1}{N} \sum_{i=1}^{N} \frac{p_{i}-o_{i}}{o_{i}}$

where $p_{i}$ represents the predicted data and $o_{i}$ represents the observational data. $N$ means the number of data points. A normalized bias less than $\pm 15 \%$ is suggested by EPA as indicative of acceptable ozone model performance. 
Table 3. Statistical comparison of the CMAQ predicted values with the observational data.

\begin{tabular}{|c|c|c|c|c|c|c|c|c|c|c|c|c|}
\hline \multirow{3}{*}{$\begin{array}{l}\text { Month } \\
\text { Pollutants } \\
\text { Item }\end{array}$} & \multicolumn{6}{|c|}{ January } & \multicolumn{6}{|c|}{ July } \\
\hline & \multicolumn{2}{|c|}{$\mathrm{SO}_{2}\left(\mathrm{mg} \mathrm{m}^{-3}\right)$} & \multicolumn{2}{|c|}{$\mathrm{NO}_{2}\left(\mathrm{mg} \mathrm{m}^{-3}\right)$} & \multicolumn{2}{|c|}{$\mathrm{PM}_{10}\left(\mathrm{mg} \mathrm{m}^{-3}\right)$} & \multicolumn{2}{|c|}{$\mathrm{SO}_{2}\left(\mathrm{mg} \mathrm{m}^{-3}\right)$} & \multicolumn{2}{|c|}{$\mathrm{NO}_{2}\left(\mathrm{mg} \mathrm{m}^{-3}\right)$} & \multicolumn{2}{|c|}{$\mathrm{PM}_{10}\left(\mathrm{mg} \mathrm{m}^{-3}\right)$} \\
\hline & Obs & Model & Obs & Model & Obs & Model & Obs & Model & Obs & Model & Obs & Model \\
\hline $\begin{array}{l}\text { Hourly } \\
\text { Average }\end{array}$ & 0.045 & 0.052 & 0.043 & 0.05 & 0.083 & 0.041 & 0.036 & 0.039 & 0.033 & 0.038 & 0.017 & 0.018 \\
\hline Max. & 0.19 & 0.337 & 0.121 & 0.119 & 0.274 & 0.109 & 0.181 & 0.297 & 0.11 & 0.111 & 0.050 & 0.057 \\
\hline Min. & 0.004 & 0.001 & 0.007 & 0.007 & 0.000 & 0.000 & 0.005 & 0.003 & 0.005 & 0.002 & 0.000 & 0.000 \\
\hline $\begin{array}{l}R^{2} \text { correlation } \\
\text { coefficient }\end{array}$ & \multicolumn{2}{|c|}{0.51} & \multicolumn{2}{|c|}{0.66} & \multicolumn{2}{|c|}{0.4} & \multicolumn{2}{|c|}{0.69} & \multicolumn{2}{|c|}{0.64} & \multicolumn{2}{|c|}{0.52} \\
\hline $\begin{array}{l}\text { Index of } \\
\text { agreement }\end{array}$ & \multicolumn{2}{|c|}{0.55} & \multicolumn{2}{|c|}{0.79} & \multicolumn{2}{|c|}{0.45} & \multicolumn{2}{|c|}{0.79} & \multicolumn{2}{|c|}{0.75} & \multicolumn{2}{|c|}{0.53} \\
\hline Bias & \multicolumn{2}{|c|}{$25 \%$} & \multicolumn{2}{|c|}{$29 \%$} & \multicolumn{2}{|c|}{$-24 \%$} & \multicolumn{2}{|c|}{$13 \%$} & \multicolumn{2}{|c|}{$22 \%$} & \multicolumn{2}{|c|}{$26 \%$} \\
\hline Factor of two & \multicolumn{2}{|c|}{$59 \%$} & \multicolumn{2}{|c|}{$80 \%$} & \multicolumn{2}{|c|}{$51 \%$} & \multicolumn{2}{|c|}{$75 \%$} & \multicolumn{2}{|c|}{$81 \%$} & \multicolumn{2}{|c|}{$73 \%$} \\
\hline $\begin{array}{l}\text { Number of } \\
\text { data points }\end{array}$ & \multicolumn{2}{|c|}{960} & \multicolumn{2}{|c|}{960} & \multicolumn{2}{|c|}{480} & \multicolumn{2}{|c|}{1200} & & 00 & & 80 \\
\hline
\end{tabular}

The index of agreement is calculated by Eq. (3) as described above.

The statistical results comparing predicted values and observation data are given in Table 3. Table 3 shows that the correlation coefficients between prediction and observational data are mostly $>0.5$. The indexes of agreement of $\mathrm{SO}_{2}$, $\mathrm{NO}_{2}$, and $\mathrm{PM}_{10}$ are $0.55,0.79$, and 0.45 , respectively, in January; and $0.79,0.75,0.53$ in July. The CMAQ model overpredicts $\mathrm{SO}_{2}$ and $\mathrm{NO}_{2}$ concentrations by about $13-25 \%$ and $22-29 \%$, while it underpredicts $\mathrm{PM}_{10}$ by about $24 \%$ in January and overpredicts by about $25 \%$ in July. The model performance for summer is better than winter. The reason for overprediction of $\mathrm{SO}_{2}, \mathrm{NO}_{2}$, and underestimation of $\mathrm{PM}_{10}$ is possibly due to underestimation of $\mathrm{NH}_{3}$ emissions. The secondary transformation process is underestimated as a result. In winter, the meteorological dispersion conditions in the YRD are not good, generally with low precipitation, and frequent inversions; such complex meteorological conditions are not well simulated by meteorological models. For example, the wind speed obtained by MM5 is often overestimated and then the model results for winter are not as good as for summer. Although there are some biases in the model performance, these biases are generally within acceptable ranges.

\section{Regional air quality model results and discussion}

\subsection{Ozone}

Figure 13 shows the monthly average (the monthly mean of hourly average of the air pollutants) concentrations of $\mathrm{O}_{3}$ and $\mathrm{NO}_{2}$ in the 16 cities of the YRD. In January, the monthly average concentration of $\mathrm{O}_{3}$ is $0.052 \pm 0.011 \mathrm{mg} \mathrm{m}^{-3}$, and
$0.054 \pm 0.008 \mathrm{mg} \mathrm{m}^{-3}$ in July. In the clean atmosphere away from its sources, NO represents generally less than one third of $\mathrm{NO}_{\mathrm{x}}$ during the day, and is rapidly titrated after sunset by ozone. In contrast, in the polluted atmosphere, such as in urban areas, where NO is constantly emitted from the surface, ozone is slowly titrated by NO throughout the night, forming high $\mathrm{NO}_{2}$ mixing ratios. The correlation between the $\mathrm{O}_{3}$ and $\mathrm{NO}_{2}$ concentrations shows that the two pollutants are negatively correlated, with a correlation coefficient of -0.85 , as shown in Fig. 14. This result agrees with the observational work of Wang et al. (2001a).

To illustrate the formation and dissipation of ozone, Fig. 15 presents the variation of hourly $\mathrm{O}_{3}$ concentration on 5 July 2004, when the highest hourly ozone concentration occurs during the modeling period. The spatial distribution of ground-level $\mathrm{O}_{3}$, influenced by meteorological conditions, varies with time. After the sun rises, the $\mathrm{O}_{3}$ concentration gradually increases. As time goes by, the primary air pollutants including $\mathrm{NO}_{\mathrm{x}}$ and VOCs diffuse from urban areas to the downwind region, where the high $\mathrm{O}_{3}$ concentration occurs due to photochemical reaction. By 13:00-15:00 LT, the high hourly $\mathrm{O}_{3}$ concentration covers the cities of Shaoxing, Hangzhou, Huzhou, and Jiaxing. The highest hourly concentration of $\mathrm{O}_{3}$ on July 5 reached $0.24 \mathrm{mg} \mathrm{m}^{-3}(110 \mathrm{ppb})$ in the grid cell $(111,25)$ (Zhoushan City) at 13:00 LT. In Shanghai city, the figure shows obvious differences of $\mathrm{O}_{3}$ concentrations at different locations. The ozone concentration in the urban area is lower than that in the rural area, because the emission characteristics in different regions of the city vary significantly and the high $\mathrm{O}_{3}$ concentration is titrated by $\mathrm{NO}$ in the urban area with strong $\mathrm{NO}_{\mathrm{x}}$ emissions. This result agrees with the work of Geng et al. (2008), who found that 

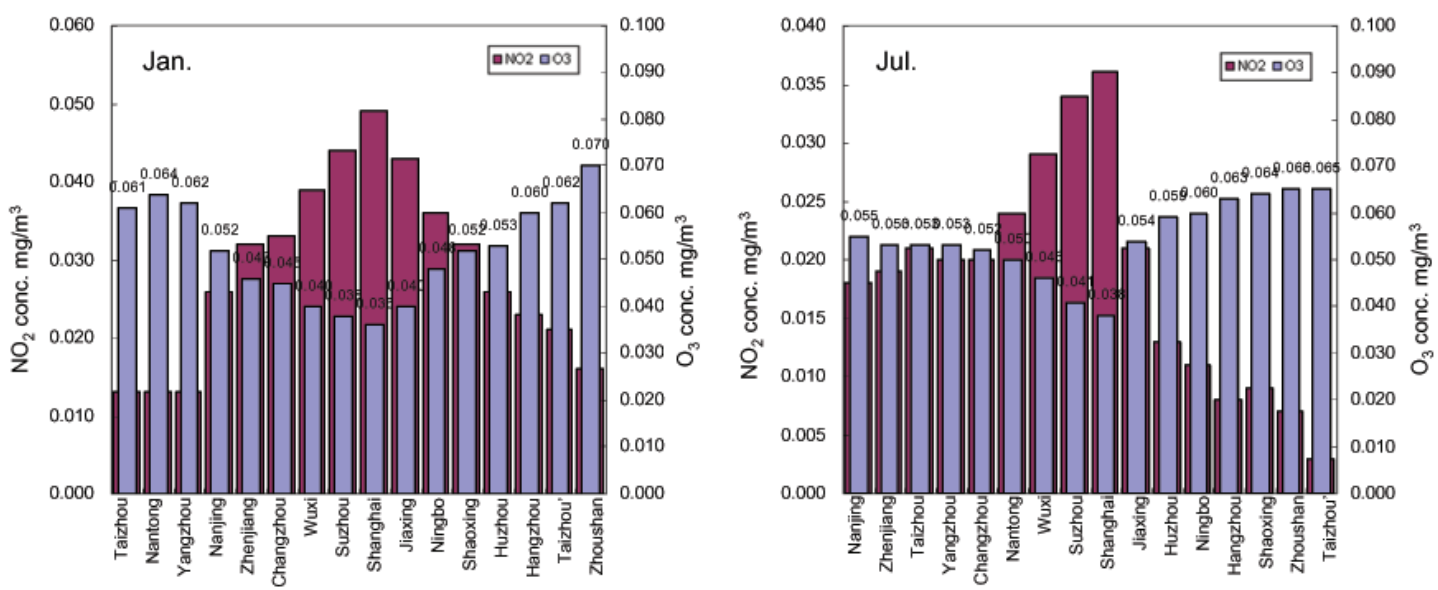

Fig. 13. Monthly average concentrations of $\mathrm{O}_{3}$ among the 16 cities in the YRD.
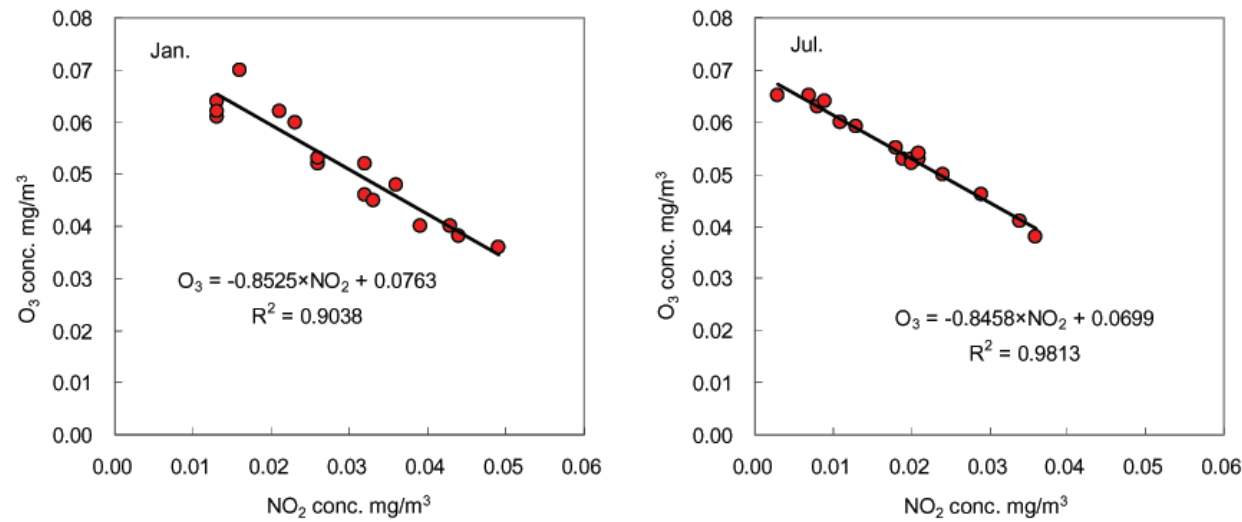

Fig. 14. Correlation between monthly average concentrations of $\mathrm{O}_{3}$ and $\mathrm{NO}_{2}$ in 16 cities in the YRD.

the $\mathrm{O}_{3}$ concentration is highest in the rural area that has low emissions of $\mathrm{O}_{3}$ precursors. In contrast, the $\mathrm{O}_{3}$ concentration in the urban area is low due to the $\mathrm{O}_{3}$ suppression processes caused by urban emissions.

\subsection{Visibility}

Visibility in the YRD is often poor, as can be readily observed by residents and visitors. This paper applies the concept of deciview (dcv) to reflect the visibility status. This indicator is calculated based on the extinction coefficient shown in Eq. (6).

$\mathrm{dV}=10 \ln (\beta / 0.01)$

where $\mathrm{dV}$ means deciview, and $\beta$ represents the extinction coefficient, which is the sum of the scattering and absorption coefficients.

In the United States, dcv is usually divided into five classes to reflect the subjective visibility levels, as shown in Table 4 . Figure 16 shows the monthly average dev values for the 16 major YRD cities obtained from the MM5-CMAQ model.
Table 4. Deciview values and corresponding visibility levels.

\begin{tabular}{ll}
\hline Dcv & Visibility level \\
\hline$\leq 14$ & Very good \\
$15-20$ & Good \\
$21-24$ & Moderate \\
$25-28$ & Bad \\
$\geq 29$ & Very bad \\
\hline
\end{tabular}

The results show that the dcv values of the various cities in winter are $>20$, with an average value of $26.4 \pm 2.95 \mathrm{dcv}$, while the average visibility in summer is $17.6 \pm 3.3 \mathrm{dcv}$. As CMAQ underestimates $\mathrm{PM}_{10}$ concentrations about $24 \%$ in January and overpredicts about $26 \%$ in July, it can be inferred that $\mathrm{PM}_{2.5}$ concentrations may also be underestimated in January and overpredicted in July, which indicates that the visibility should be worse than the simulation in January and better than modeling results in July. This shows that the 

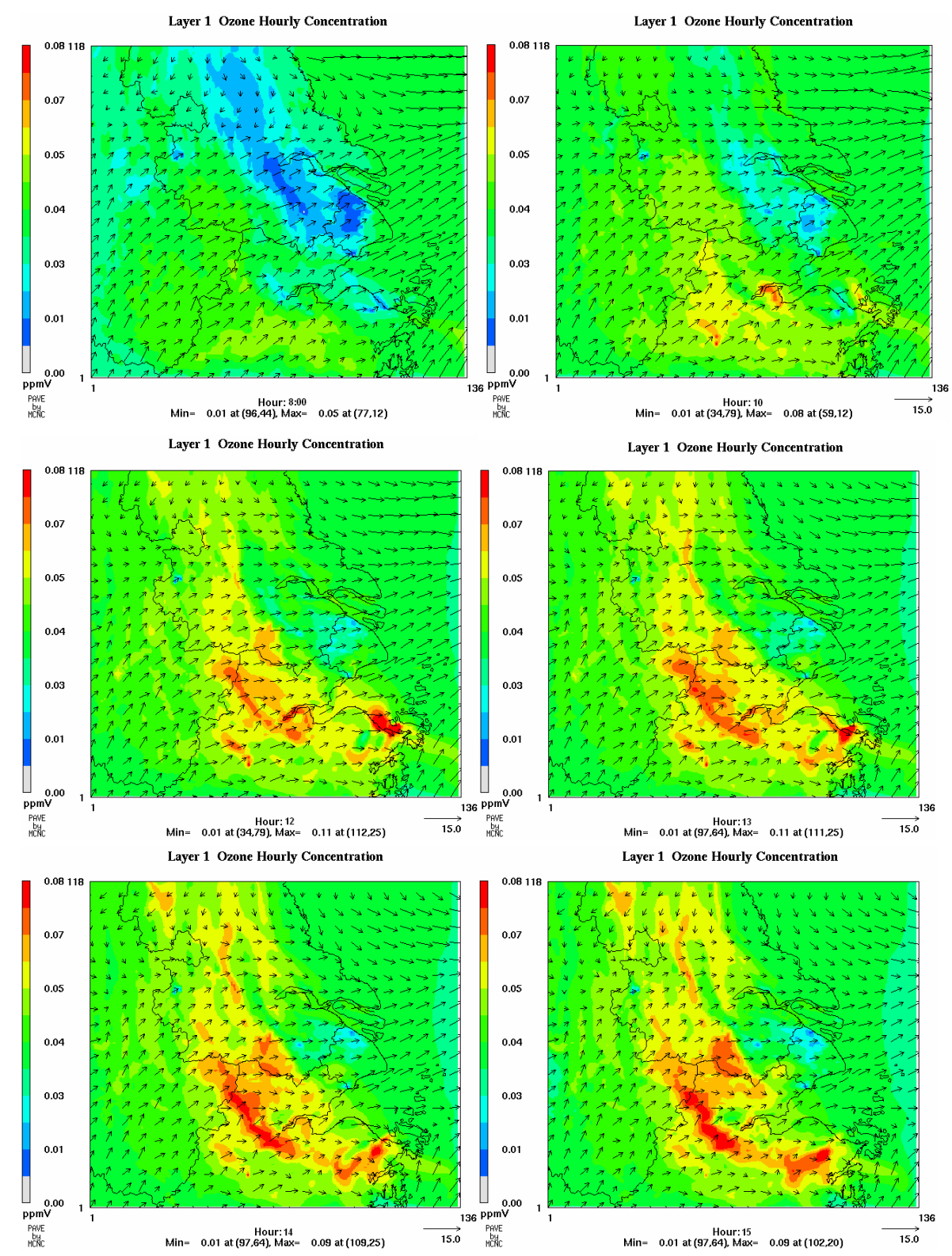

Fig. 15. Spatial distributions of hourly $\mathrm{O}_{3}$ concentrations on 5 July 2004.

visibility in the YRD in winter is quite bad, while it is relatively better in summer. This is mainly because the dominant wind in summer is southeast, which is from the East China Sea. Clean marine air makes the air quality good in summer. However, in winter, the meteorological conditions are not good for air pollutants to disperse. The precipitation is rare, and frequency of inversion is high, which causes the air pollutants to accumulate readily. Thus the visibility in winter is relatively bad. Related studies show that visibility is strongly negatively correlated with $\mathrm{PM}_{2.5}$, with a correlation coefficient of -0.68 (Huang et al., 2009). It is clear that $\mathrm{PM}_{2.5}$ concentrations in the YRD cities are worse in the winter than in the summer, leading to poor visibility in winter.
This result agrees with the work of Wang et al. (2006) and Ye et al. (2003), who found that the seasonal variation of ion and $\mathrm{PM}_{2.5}$ concentrations was significant, with the highest concentrations observed in winter and spring and the lowest in summer and autumn.

Figure 17 shows the daily average dcv values for 10 January and 10 July 2004. Comparing the two images, we can see quite clearly that the visibility in winter is much worse than summer. In winter, the visibility in the center of the YRD - Hangzhou, Huzhou, Nanjing, Wuxi, and Changzhou cities - can be quite bad. While in the more eastern and southern areas, like Shanghai and Zhoushan, it is relatively better. 

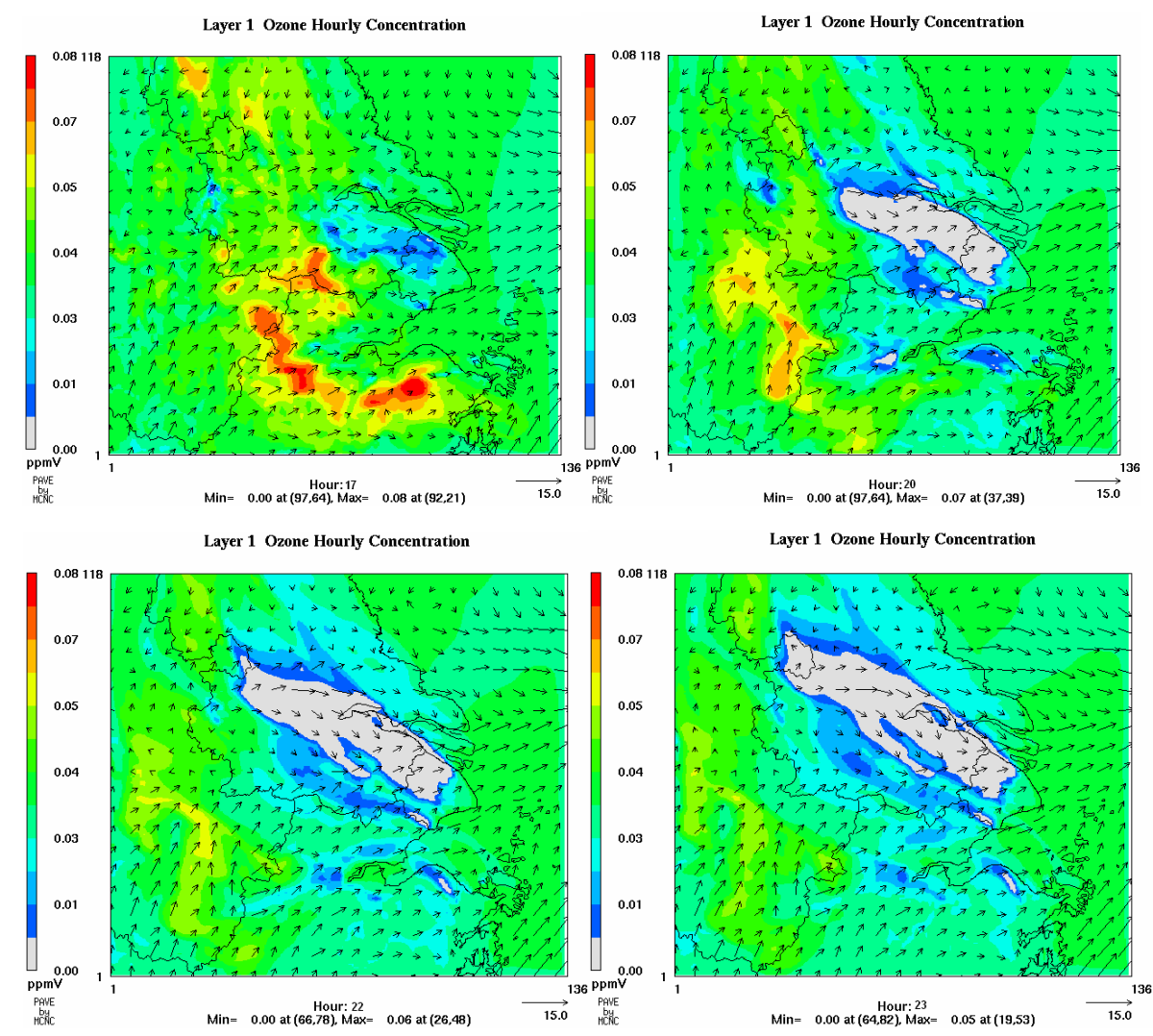

Fig. 15. Continued.

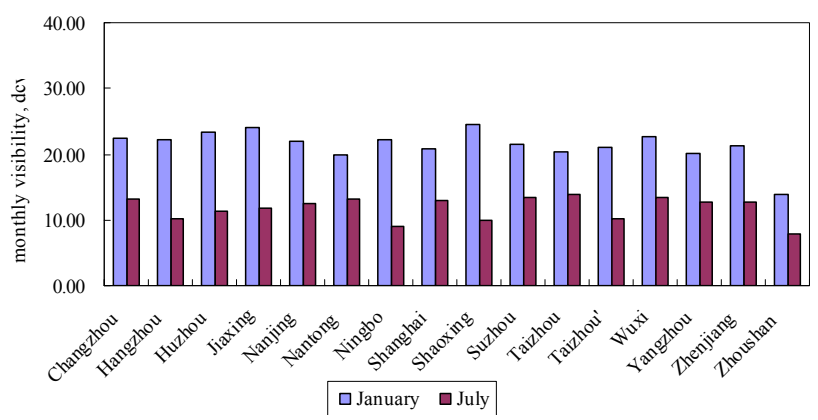

Fig. 16. Visibility, measured as deciview (dcv), in the 16 cities of the YRD.

\subsection{Other pollutants}

Figure 18 shows the monthly average concentrations of $\mathrm{SO}_{2}$ in the 16 cities of the YRD. In January, the monthly average concentration of $\mathrm{SO}_{2}$ is $0.035 \pm 0.015 \mathrm{mg} \mathrm{m}^{-3}$, and $0.019 \pm 0.010 \mathrm{mg} \mathrm{m}^{-3}$ in July. As CMAQ overpredicts $\mathrm{SO}_{2}$ concentrations by about $25 \%$ in January and $13 \%$ in July, we may anticipate that the real monthly average concentrations of $\mathrm{SO}_{2}$ in the YRD in January and July are $0.026 \pm 0.011 \mathrm{mg} \mathrm{m}^{-3}$, and $0.017 \pm 0.009 \mathrm{mg} \mathrm{m}^{-3}$, respec- tively. Due to the air pollution transport from Northern China to the YRD, together with the high local emissions, the regional $\mathrm{SO}_{2}$ pollution in winter is worse than in summer. The pollution centers include Shanghai, Suzhou, Jiaxing, and Ningbo. In summer, due to inflow of clean air from the sea to the southeast, the $\mathrm{SO}_{2}$ concentrations in cities are lower. The $\mathrm{SO}_{2}$ concentrations in southern cities are obviously better than in the northern ones.

Figure 19 shows the monthly average concentrations of $\mathrm{NO}_{2}$ in the 16 cities of the YRD. In January, the monthly average concentration of $\mathrm{NO}_{2}$ is $0.029 \pm 0.012 \mathrm{mg} \mathrm{m}^{-3}$, and $0.018 \pm 0.010 \mathrm{mg} \mathrm{m}^{-3}$ in July. As CMAQ overpredicts $\mathrm{NO}_{2}$ concentrations by about $29 \%$ in January and $22 \%$ in July, we may anticipate that the real monthly average concentrations of $\mathrm{NO}_{2}$ in the YRD in January and July are $0.021 \pm 0.009 \mathrm{mg} \mathrm{m}^{-3}$, and $0.014 \pm 0.008 \mathrm{mg} \mathrm{m}^{-3}$, respectively. Similar to $\mathrm{SO}_{2}$, Shanghai is also the high pollution center of $\mathrm{NO}_{2}$. Comparisons between winter and summer show that, although there is clean air inflow from the sea in summer, the difference between seasons are not so obvious as for $\mathrm{SO}_{2}$, which is due to the vehicle emissions in cities. In addition, in summer, due to use of air conditioners in the cars, the emissions are relatively higher than in winter. This result is consistent with the work of Uno et al. (2007), who found that the seasonal variation of $\mathrm{NO}_{2}$ over 
Layer 1 DCV_Daily Avg
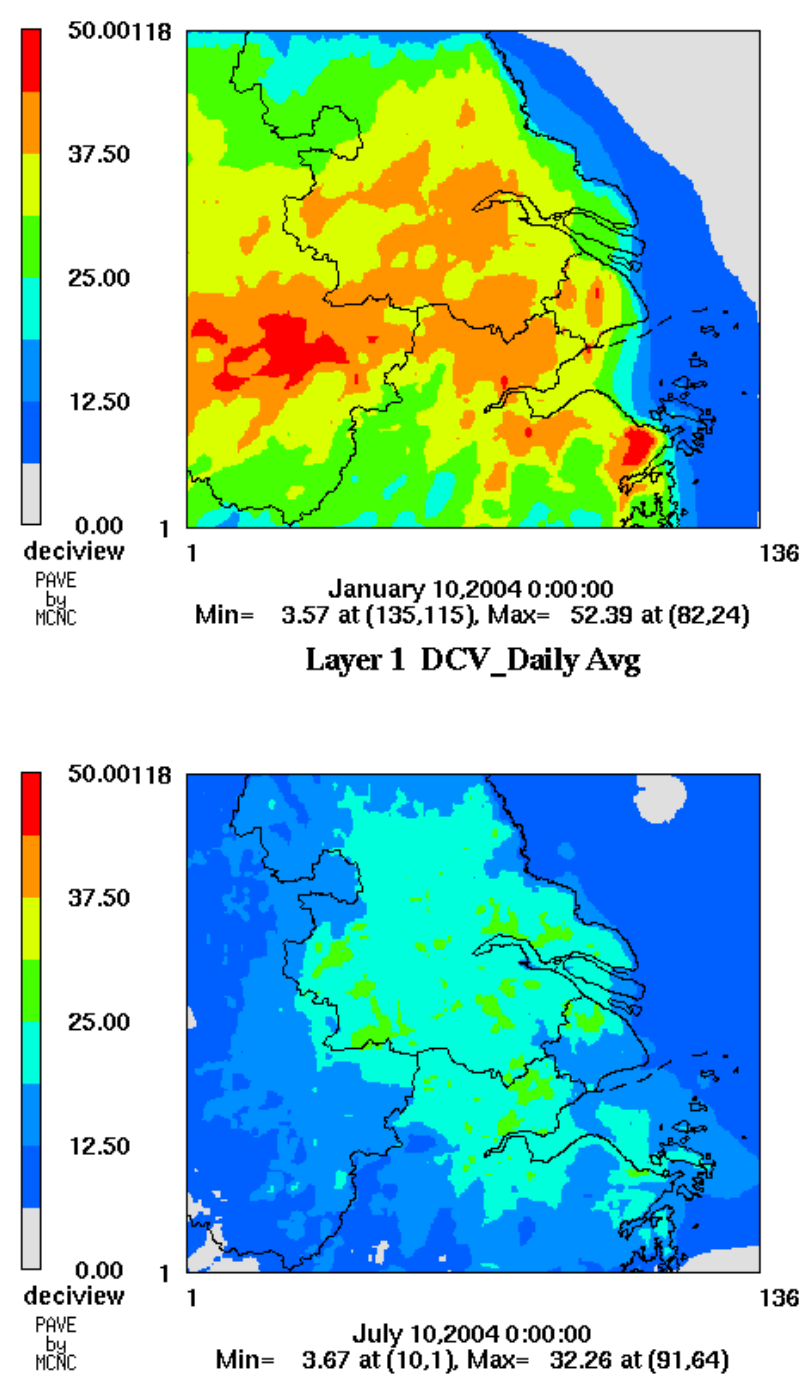

Fig. 17. Modeled visibility in the YRD.

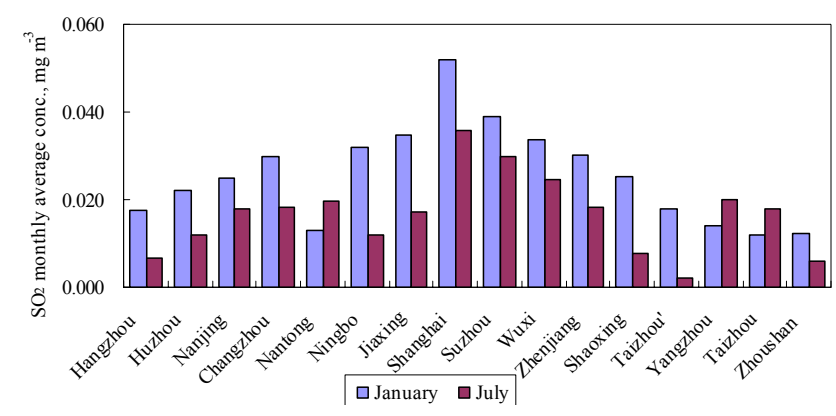

Fig. 18. Monthly average concentrations of $\mathrm{SO}_{2}$ in the 16 cities of the YRD.

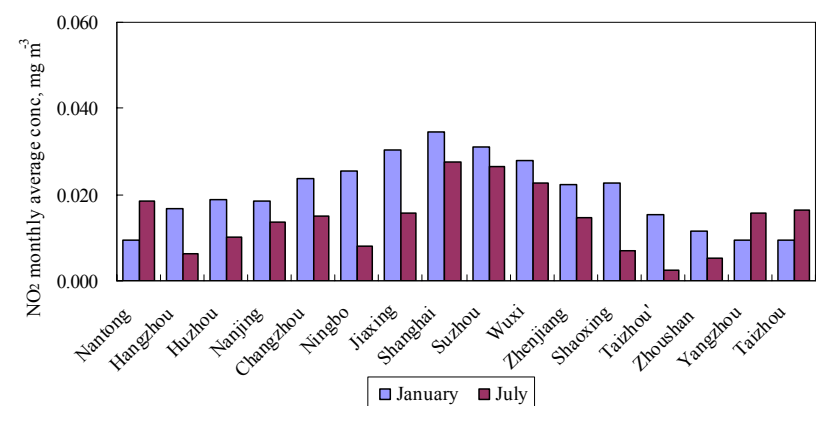

Fig. 19. Monthly average concentrations of $\mathrm{NO}_{2}$ in the 16 cities of the YRD.

East Asia shows a summer (July-August) minimum and a winter (December) maximum. The result is also similar to that of Wang et al. (2009), who presented a seasonal variation in $\mathrm{NO}_{2}$ columns in the YRD region that showed higher $\mathrm{NO}_{2}$ in winter due to the longer lifetime of $\mathrm{NO}_{2}$ and greater $\mathrm{NO}_{\mathrm{x}}$ emissions in the region.

Figure 20 shows the monthly average concentrations of $\mathrm{PM}_{10}$ in the 16 cities of the YRD. In January, the monthly average concentration of $\mathrm{PM}_{10}$ is $0.064 \pm 0.023 \mathrm{mg} \mathrm{m}^{-3}$, and $0.034 \pm 0.021 \mathrm{mg} \mathrm{m}^{-3}$ in July. As CMAQ underpredicts $\mathrm{PM}_{10}$ concentrations by about $24 \%$ in January and overpredicts about $26 \%$ in July, we may anticipate that the real monthly average concentrations of $\mathrm{PM}_{10}$ in the YRD in January and July are $0.080 \pm 0.028 \mathrm{mg} \mathrm{m}^{-3}$, and $0.025 \pm 0.015 \mathrm{mg} \mathrm{m}^{-3}$, respectively. The regional $\mathrm{PM}_{10}$ pollution in winter is much worse than in summer. The pollution centers in winter include Shanghai, Jiaxing, and Shaoxing.

\section{Conclusions}

This paper applies the MM5-CMAQ modeling system to the study of regional air pollution in the YRD. Model performance studies show that the system can reliably reproduce the air pollution situation in the region. Model performance results indicate that the correlation coefficients between prediction and observational data are greater than 0.5. The indexes of agreement for $\mathrm{SO}_{2}, \mathrm{NO}_{2}$, and $\mathrm{PM}_{10}$ are 0.55-0.79, $0.75-0.79$, and $0.45-0.53$, respectively. The CMAQ model tends to overpredict $\mathrm{SO}_{2}$ and $\mathrm{NO}_{2}$ concentrations by about $13-25 \%$ and $22-29 \%$, while it underpredicts $\mathrm{PM}_{10}$ by about $24 \%$ in January and overpredicts by about $25 \%$ in July. The model performance for summer is better than winter. The model performance assessments show that the model results are acceptable for this application.

Observational data show that the ozone concentrations in summer are quite high, while the visibility in winter is bad. Model results show that the highest hourly concentration of $\mathrm{O}_{3}$ on 5 July reached $110 \mathrm{ppb}$, which appeared at 13:00 LT in Zhoushan City, slightly lower than the observed value. The results also show that the deciview values 


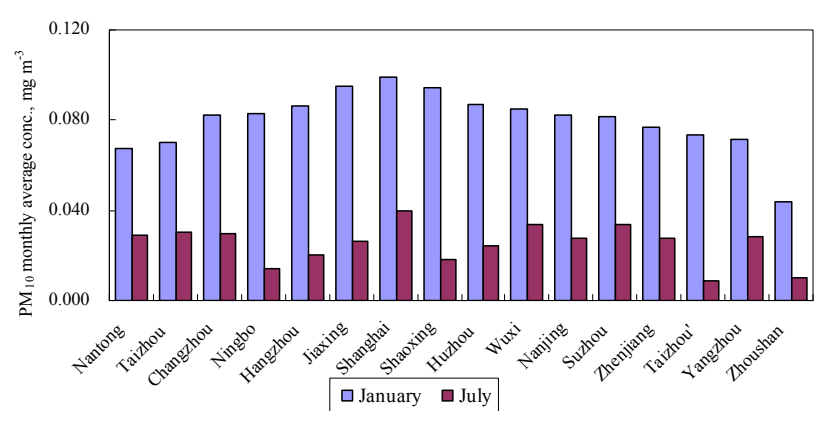

Fig. 20. Monthly average concentrations of $\mathrm{PM}_{10}$ in the 16 cities of the YRD.

for various cities in winter are larger than 20 , with an average value of $26.4 \pm 2.95 \mathrm{dcv}$, while the average visibility in summer is $17.6 \pm 3.3 \mathrm{dcv}$. The monthly average concentration of $\mathrm{SO}_{2}$ in January is $0.026 \pm 0.011 \mathrm{mg} \mathrm{m}^{-3}$, and $0.017 \pm 0.009 \mathrm{mg} \mathrm{m}^{-3}$ in July. The monthly average concentrations of $\mathrm{NO}_{2}$ in the YRD in January and July are $0.021 \pm 0.009 \mathrm{mg} \mathrm{m}^{-3}$, and $0.014 \pm 0.008 \mathrm{mg} \mathrm{m}^{-3}$, respectively. Monthly average concentrations of $\mathrm{PM}_{10}$ in the YRD in January and July are $0.080 \pm 0.028 \mathrm{mg} \mathrm{m}^{-3}$, and $0.025 \pm 0.015 \mathrm{mg} \mathrm{m}^{-3}$, respectively. Due to pollutant transport from Northern China to the YRD, the unfavorable meteorological dispersion conditions, and the high local emissions, the regional $\mathrm{SO}_{2}$ pollution in winter is worse than in summer. Clearly, elevated $\mathrm{O}_{3}$ episodes are occurring in the YRD, and regional haze is becoming more obvious. These results confirm the conclusions reached by Chan and Yao (2008), who reviewed the current state of understanding of the air pollution problems in Shanghai. However, details of these episodes, such as the frequency, the weather conditions, and the temporal and spatial variations of $\mathrm{O}_{3}$ and haze, can vary significantly with geographical location within the region. Currently, ozone and haze have become extremely important issues in regional air quality. The YRD is presently undergoing tremendous economic growth, and the threat of high regional pollutant emissions and high pollution is very real. In this point, we recommend that integrated measures be taken together in all the cities to improve the regional air pollution situation in the YRD.

Acknowledgements. This study was supported by the "Chinese National Key Technology R\&D Program” via grants 2009BAK43B33. The authors would like to thank US EPA for providing the CMAQ model code, full model documentation, and assistance with model set-up and running. We also appreciate the suggestions made by the two kind reviewers that helped greatly to improve this paper.

Edited by: C. K. Chan

\section{References}

Akimoto, $\mathrm{H}$. and Narita, $\mathrm{H}$.: Distribution of $\mathrm{SO}_{2}, \mathrm{NO}_{\mathrm{x}}$ and $\mathrm{CO}_{2}$ emissions from fuel combustion and industrial activities in Asia with $1^{\circ} \times 1^{\circ}$ resolution, Atmos. Environ., 28, 213-225, 1994 .

An, X., Zhu, T., Wang, Z., Li, C., and Wang, Y.: A modeling analysis of a heavy air pollution episode occurred in Beijing, Atmos. Chem. Phys., 7, 3103-3114, doi:10.5194/acp-7-3103-2007, 2007.

Byun, D. W. and Ching, J. K. S.: Science algorithms of the EPA Models-3 Community Multiscale Air Quality (CMAQ) modeling system, US Environmental Protection Agency Report EPA/600/R-99/030, Research Triangle Park, NC, 1999.

Byun, D. W., Ching, J. K. S., Novak, J., and Young, J.: Development and implementation of the EPA's Models-3 initial operating version: Community Multi-scale Air Quality (CMAQ) Model, Plenum Publishing Corp, New York, USA, 1998.

Carmichael, G. R., Tang, Y., Kurata, G., Uno, I., Streets, D. G., Thongboonchoo, N., Woo, J.-H., Guttikunda, S., White, A., Wang, T., Blake, D. R., Atlas, E., Fried, A., Potter, B., Avery, M. A., Sachse, G. W., Sandholm, S. T., Kondo, Y., Talbot, R. W., Bandy, A., Thornton, D., and Clarke, A. D.: Evaluating regional emission estimates using the TRACE-P observations, J. Geophys. Res., 108, 8810, doi:10.1029/2002JD003116, 2003.

Chameides, W. L., Li., X., Tang, X., Zhou, X., Chao, L., Kiang, C. S., St. John., J., Saylor, R. D., Liu, S. C., Lam, K. S., Wang, T., and Giorgi, F.: Is ozone pollution affecting crop yields in China?, Geophys. Res. Lett., 26, 867-870, 1999.

Chan, C. K. and Yao, X. H.: Air pollution in mega cities in China, Atmos. Environ., 42, 1-42, 2008.

Chen, F. and Dudhia J.: Coupling and advanced landsurface/hydrology model with the Penn State/NCAR MM5 modeling system, Part I: model implementation and sensitivity, Mon. Wea. Rev., 129, 569-585, 2001.

Chen, S. J., Tong, J. C., Kazuhiko, K. B, and Zhu, J. G.: Influences of the meteorological factors on the ozone concentration near the ground, Journal of Central China Normal University, Nat. Sci., 39, 273-277, 2005 (in Chinese).

Cheung, V. T. F. and Wang, T.: Observational study of ozone pollution at a rural site in the Yangtze River Delta of China, Atmos. Environ., 35, 4947-4958, 2001.

Dennis, R. L., Byun, D. W., Novak J. H., Galluppi K. J., Coats, C. J., and Vouk, M. A.: The next generation of integrated air quality modeling: EPA's Models-3, Atmos. Environ., 30, 1925-1938, 1996.

Di, X. H., Nie, Z. R., and Zuo, T. Y.: Life cycle emission inventories for the fuels consumed by thermal power in China, China Environmental Science, 25, 632-635, 2005(in Chinese).

Fang, P. X., Jiang, X., and Xi, Y. F.: Environmental Statistics Manual, Sichuan Science and Technology Press, Chengdu, China, 1985(in Chinese).

Finlayson-Pitts, B. J. and Pitts, J. N.: Atmospheric chemistry of tropospheric ozone formation: scientific and regulatory implications, J. Air Waste Manage., 43, 1091-1100, 1993.

Fu, J. S., Jang, C. J., Streets, D. G., Li, Z., Kwok, R., Park, R., and Han, Z.: MICS-Asia II: Modeling gaseous pollutants and evaluating an advanced modeling system over East Asia, Atmos. Environ., 42, 3571-3583, 2008.

Geng, F. H., Tie, X., Xu, J. M., Zhou, G. Q., Peng, L., Gao, W., Tang, X., and Zhao, C. S.: Characterizations of ozone, NOx, and 
VOCs measured in Shanghai, China, Atmos. Environ., 42, 68736883, 2008.

Han, Z. W., Hiromasa, U., An, J. L., Evaluation and intercomparison of meteorological predictions by five MM5-PBL parameterizations in combination with three land-surface models, Atmos. Environ., 42, 233-249, 2008.

Huang, W., Tan, J., Kan, H. D., Zhao, N., Song, W. M., Song, G. X., Chen, G. H., Jiang, L. L., Jiang, C., Chen, R. J., and Chen, B. H.: Visibility, air quality and daily mortality in Shanghai, China, Sci. Total. Environ., 407, 3295-3300, 2009.

Hu, M. C.: Environmental protection data manual, China Machine Press, Beijing, China, 1990(in Chinese).

Jiangsu Statistical Yearbook, China Statistics Press, Beijing, China, 2005.

Kato, N. and Akimoto, H.: Anthropogenic emissions of SO2 and NOx in Asia: emission inventories, Atmos. Environ., 26A, 29973017, 1992.

Kuang, J. X., Long, T., Huang, Q. F., and Jian, J. Y.: Study of emission factor for burning fuel, Environmental Monitoring in China, 17, 27-30, 2001(in Chinese).

Lamb, R. G.: A regional-scale $(1000 \mathrm{~km})$ model of photochemical air pollution: Part I. theoretical formulation, U.S. Environmental Protection Agency Report EPA/600/3-85-035, Research Triangle Park, NC, 1982.

Li, L., Chen, C. H., Huang, C., Huang, H. Y., Li, Z. P., Fu, J. S., Carey, J. J., and Streets, D. G.: Regional air pollution characteristics simulation of $\mathrm{O}_{3}$ and $\mathrm{PM}_{10}$ over Yangtze River Delta Region, Environmental Science, 29, 237-245, 2008(in Chinese).

Lin, M., Holloway, T., Oki, T., Streets, D. G., and Richter, A.: Multi-scale model analysis of boundary layer ozone over East Asia, Atmos. Chem. Phys., 9, 3277-3301, doi:10.5194/acp-93277-2009, 2009.

Luo, C., St. John, J., Zhou, X., Lam, K., Wang, T., and Chameides, W.: A nonurban ozone air pollution episode over Eastern China: observations and model simulations, J. Geophys. Res., 105(D2), 1889-1908, 2000.

Ministry of Environmental Protection (MEP) of the People's Republic of China: User's Guide on the Production and Emission Factors of Industrial Pollutants, China Environmental Science Press, Beijing, China, 1996.

Pielke, R. A.: Mesoscale Meteorology Simulation, Meteorology Press, Beijing, China, 1990.

Shanghai Statistical Yearbook: China Statistics Press, Beijing, China, 2005.

Streets, D. G. and Waldhoff, S. T.: Present and future emissions of air pollutants in China: $\mathrm{SO}_{2}, \mathrm{NO}_{\mathrm{x}}$ and $\mathrm{CO}$, Atmos. Environ., 34, 363-374, 2000.

Streets, D. G., Jiang K., Hu X., Sinton, J. E., Zhang, X.-Q., Xu, D., Jacobson, M. Z., and Hanson, J. E.: Recent reductions in China's greenhouse-gas emissions, Science, 294, 1835-1836, 2001.

Streets, D. G., Bond, T. C., Carmichael, G. R., Fernandes, S. D., Fu, Q., He, D., Klimont, Z., Nelson, S. M., Tsai, N. Y., Wang, M. Q., Woo, J.-H., and Yarber, K. F.: An inventory of gaseous and primary aerosol emissions in Asia in the year 2000, J. Geophys. Res., 108, 8809, doi:10.1029/2002JD003093, 2003a.

Streets, D. G., Yarber, K. F., Woo, J.-H., and Carmichael, G. R.: Biomass burning in Asia: annual and seasonal estimates and atmospheric emissions, Global Biogeochem. Cycles, 17, 1099, doi:10.1029/2003GB002040, 2003b.
Streets, D. G., Fu, J. S., Jang, C. J., Hao, J., He, K., Tang, X., Zhang, Y., Wang, Z., Li, Z., Zhang, Q., Wang, L., Wang, B., and Yu, C.: Air quality during the 2008 Beijing Olympic Games, Atmos. Environ., 41, 480-492, 2007.

Tesche, T. W.: Photochemical dispersion modeling: review of model concepts and applications studies, Environ. Intl., 9, 46548, 1983.

United States Environmental Protection Agency: AP-42 Emission Factors, Washington, DC, 2006.

Uno, I., He, Y., Ohara, T., Yamaji, K., Kurokawa, J.-I., Katayama, M., Wang, Z., Noguchi, K., Hayashida, S., Richter, A., and Burrows, J. P.: Systematic analysis of interannual and seasonal variations of model-simulated tropospheric $\mathrm{NO}_{2}$ in Asia and comparison with GOME-satellite data, Atmos. Chem. Phys., 7, 16711681, doi:10.5194/acp-7-1671-2007, 2007.

Wang T., Cheung V. T. F., Anson, M., and Li, Y. S.: Ozone and related gaseous pollutants in the boundary layer of eastern China: overview of the recent measurements at a rural site, Geophys Res. Lett., 28, 2373-2376, 2001a.

Wang, X. M., Fu, C., and Liang, G. X.: Study on the ozone concentration in urban areas, Research of Environmental Sciences, 14, 1-3, $2001 \mathrm{~b}$.

Wang, H. X., Tang, X. Y., Wang, M. L., Yan, P., Wang, T., Shao, K. S., Zeng, L. M., Du, H. F., and Chen, L. M.: The temporal and spatial allocation characteristics of trace gases in the Yangtze River Delta, Science in China (Series D), 33, 114-118, 2003(in Chinese).

Wang, Y., Zhuang, G. S., Zhang, X. Y., Huang, K., Xu, C., Tang, A. H., Chen, J. M., and An, Z. S.: The ion chemistry, seasonal cycle, and sources of $\mathrm{PM}_{2.5}$ and TSP aerosol in Shanghai, Atmos. Environ., 40, 2935-2952, 2006.

Wang, T., Wei, X. L., Ding, A. J., Poon, C. N., Lam, K. S., Li, Y. S., Chan, L. Y., and Anson, M.: Increasing surface ozone concentrations in the background atmosphere of Southern China, 19942007, Atmos. Chem. Phys., 9, 6217-6227, doi:10.5194/acp-96217-2009, 2009.

Wang, X., Zhang, Y., Hu, Y., Zhou, W., Lu, K., Zhong, L., Zeng, L., Shao, M., Hu, M., and Russell, A. G.: Process analysis and sensitivity study of regional ozone formation over the Pearl River Delta, China, during the PRIDE-PRD2004 campaign using the Community Multiscale Air Quality modeling system, Atmos. Chem. Phys., 10, 4423-4437, doi:10.5194/acp-5 10-4423-2010, 2010.

Xu, J., Zhu, Y., and Li. J.: Case studies on the processes of surface ozone pollution in Shanghai, J. Air Waste Manage., 49, 716-724, 1999.

Ye, B. M., Ji, X. L., Yang, H. Z., Yao, X. H., Chan, C. K., Cadle, S. H., Chan, T., and Mulawa, P. A.: Concentration and chemical composition of $\mathrm{PM}_{2.5}$ in Shanghai for a 1-year period, Atmos. Environ, 37, 499-510, 2003.

Zhang, M. G.: Numerical simulation with a comprehensive chemical transport model of nitrate, sulfate, and ammonium aerosol distributions over East Asia, China Part., 3, 255-259, 2005.

Zhang, M. G., Uno, I., Yoshida, Y., Xu, Y. F., Wang, Z. F., Akimoto, H., Bates, T., Quinn, T., Bandy, A., and Blomquist, B.: Transport and transformation of sulfur compounds over East Asia during the TRACE-P and ACE-Asia campaigns, Atmos. Environ., 38, 6947-6959, 2004. 
Zhang, M. G., Han, Z. W., and Zhu, L. Y.: Simulation of atmospheric aerosols in East Asia using modeling system RAMSCMAQ: Model evaluation, China Part., 5, 321-327, 2007.

Zhejiang Statistical Yearbook, China Statistics Press, Beijing, China, 2005.
Zhu, Y. X. and Xu, J. L.: Ozone pollution process in the lower atmosphere and the meteorological factors concerned, Research of Environmental Science, 7, 13-18, 1994(in Chinese). 